\title{
A comprehensive review on bioactive peptides derived from milk and milk products of minor dairy species
}

\author{
Snigdha Guha ${ }^{1 \dagger}$, Heena Sharma ${ }^{2 \dagger}$, Gaurav Kr Deshwal ${ }^{2}$ and Priyanka Singh Rao ${ }^{3^{*}}$ (D)
}

\begin{abstract}
Milk from different species has been exploited for the isolation of various functional ingredients for decades. Irrespective of the source, milk is considered as a complete food, as it provides essential nutrients required by the human body. Proteins and their fractions are valuable sources of bioactive peptides that might exert a health beneficial role in the human body such as immune-modulation, antioxidant activity, ACE-inhibitory activity, antineoplastic, anti-microbial, etc. In milk, bioactive peptides may either be present in their natural form or released from their parental proteins due to enzymatic action. The increasing interest in bioactive peptides among researchers has lately augmented the exploration of minor dairy species such as sheep, goat, camel, mithun, mare, and donkey. Alternative to cow, milk from minor dairy species have also been proven to be healthier from infancy to older age owing to their higher digestibility and other nutritive components. Therefore, realizing the significance of milk from such species and incentivized interest towards the derivatization of bioactive peptides, the present review highlights the significant research achievements on bioactive peptides from milk and milk products of minor dairy species.
\end{abstract}

Keywords: Milk protein, Bioactive peptides, Camel, Goat, Sheep, Donkey

\section{Introduction}

Milk occupies an essential component of the human diet globally. Reports suggest that dairy products are being consumed by more than 6 billion people across the world (FAO 2013). Various species have been utilized for the production of milk. The majority of milk comes from dairy cows and buffaloes followed by other minor dairy species including goats, sheep, camels, yak, mare, donkey, Mithun, etc. Each species has its significance according to its predominance in a particular region or country. However, cows contribute $85 \%$ of the world's total milk production while other minor dairy species

\footnotetext{
* Correspondence: priyanka.rao@icar.gov.in

†Snigdha Guha and Heena Sharma contributed equally to this work.

${ }^{3}$ Dairy Chemistry and Bacteriology Section, Southern Regional

Station-National Dairy Research Institute, Bengaluru 560030, India

Full list of author information is available at the end of the article
}

such as buffalo, goat, sheep, and camel contribute 11, $2.3,1.4$, and $0.2 \%$, respectively (Gerosa and Skoet 2012). Milk, a lacteal secretion from healthy milch animal, contains numerous nutrients including proteins, carbohydrates, fats, minerals, and vitamins, and thus possess a wide range of nutritional and functional properties. Although the milk composition of any species is based on the requirement of the neonate (Gobbetti et al. 2007; McGrath et al. 2016; Park 2009a), it has also been explored for additional health benefits for infants, children, and adults of mammalian species, beyond their basic nutritional role (Park 2009b) Among various nutrients, protein $(3.2 \mathrm{~g} / 100 \mathrm{~mL})$ is one of the most functionally diverse nutrients, and its level and functional properties differ among different species (Regester et al. 1997). Functionally, milk proteins provide a characteristic structure, solubility, water binding, viscosity, and heat stabilization properties to dairy products (Augustin and

(c) The Author(s). 2021 Open Access This article is licensed under a Creative Commons Attribution 4.0 International License, which permits use, sharing, adaptation, distribution and reproduction in any medium or format, as long as you give appropriate credit to the original author(s) and the source, provide a link to the Creative Commons licence, and indicate if changes were made. The images or other third party material in this article are included in the article's Creative Commons licence, unless indicated otherwise in a credit line to the material. If material is not included in the article's Creative Commons licence and your intended use is not permitted by statutory regulation or exceeds the permitted use, you will need to obtain permission directly from the copyright holder. To view a copy of this licence, visit http://creativecommons.org/licenses/by/4.0/. 
Udabage 2007; Korhonen and Pihlanto-Leppala 2004). From the nutritional point of view, the milk protein is enriched with bioactive substances. Milk protein and their fractions are valuable sources of bioactive peptides with various biological activities such as, antithrombotic, antimicrobial, antioxidative, antihypertensive, immunomodulatory, and sometimes they possess multifunctional activity (Park and Nam 2015). The importance of milk from minor dairy species is growing worldwide. Reports indicate that the world production of non-bovine milk was increased by $165 \%$ from 1983 to 2013 while bovine milk production had shown an increase by only $41 \%$ (Nuñez and de Renobales 2016). Milk from these minor species not only plays a vital role for producers but also for consumers worldwide. Intense research has been carried out on bioactive peptides, their identification, characterization, and utilization in functional foods, from cow's milk and milk products. However, since the last two decades, few studies have been focused on the exploration of proteins and their fractions from minor dairy species, particularly for the presence of bioactive peptides. The majority of the work is focused on the release of peptides during in vivo or in vitro digestion of proteins (Giacometti and Buretić-Tomljanović 2017). Hence, there still exists untapped and unexplored knowledge in milk and milk products from minor dairy species mainly in the area of bioactive peptides. To the best of our knowledge, very little and scattered information is available in the literature regarding the bioactive peptides from minor dairy species. Therefore, this review focuses on the gross composition of milk, bioactive peptides derived from milk and milk products of minor dairy species, and their physiological roles in the human body.

\section{Gross composition of milk from minor dairy species}

The main intent of milk production, for all terrestrial mammals, is to suffice the nutritional requirements of the neonates. Therefore, milk of all species broadly constitutes the same nutrients, such as proteins, carbohydrates, fat, minerals and water. In addition to these macronutrients, milk also constitutes several biologically active compounds such as growth factors, immunoglobulins, antimicrobial proteins, antibacterial peptides, and hormones, to help the neonates with various physiological functions (Alichanidis et al. 2016). However, among various species, the milk composition, both major and minor constituents, differs depending on nutritional, genetic, and environmental factors. The milk composition also determines its appropriateness as a raw material for various dairy products, its nutritive value, as well as its organoleptic and physicochemical characteristics (Alichanidis et al. 2016). Furthermore, it has also been observed that ruminant and non-ruminant milk is generally distinctive based on their composition. For instance, ruminant milk is characterized by a high total solid content with a higher fat, protein, and ash content (Medhammar et al. 2012; Potočnik et al. 2011). On the other hand, non-ruminant milk such as those of mare, donkey, and humans, constitute more lactose content (Guo et al. 2007; Martini et al. 2014) Nowadays, milk is regarded as one of the most exclusively complete foods which have become a fundamental part of the human diet. Table 1 provides the gross composition of milk across various minor dairy species covered under this review.

\section{Gross composition of protein fraction in milk of minor dairy species}

Milk proteins can be broadly divided into three major fractions, namely, casein, whey protein, and non-protein nitrogenous fraction. Milk casein is characterized as the protein that precipitates at isoelectric $\mathrm{pH}$ 4.6, whereas whey protein fraction comprises of all the other noncasein proteins which remain soluble. Milk also consists of small amounts of nitrogenous compounds, which are not part of any protein, and are known as non-protein nitrogen (NPN). This includes free amino acids, peptides, creatine, urea, ammonia, uric acid, orotic acid (Michaelidou 2008). Casein is heterogeneous and it contains four major forms: $\alpha_{\mathrm{s} 1}$-casein, $\alpha_{\mathrm{s} 2}$-casein, $\beta$-casein, and $\mathrm{k}$-casein (Eigel et al. 1984). Ruminant milk consists of casein as the major protein fraction, whereas, in nonruminant milk, whey protein content is characteristically higher than casein fraction. The casein to whey protein ratio largely varies among different species of mammals. For instance, in mare milk, the ratio is 50:50, human milk is 40:60, whereas, in sheep, goats, cows, and buffaloes, the ratio is around 80:20. Moreover, the different forms of caseins are found in different proportions in milk from different species. For example, $\beta$-casein is the dominant form in both goat and camel milk (Al Haj and Al Kanhal 2010; Kappeler et al. 2003; Moatsou et al. 2006), whereas $\beta$-casein and $\alpha_{s}$-casein are the main forms in mare milk (Malacarne et al. 2002).

Whey proteins can be further classified as $\alpha$-lactalbumin, $\beta$-lactoglobulin, immunoglobulins, blood serum albumin

Table 1 Gross composition (\%) from milk of minor dairy species

\begin{tabular}{llllll}
\hline Species & Total solids & Protein & Lactose & Fat & Ash \\
\hline Camel & 14.4 & 3.7 & 5.1 & 4.9 & 0.7 \\
Goat & 12.1 & 3.1 & 4.6 & 3.5 & 0.8 \\
Sheep & 16.3 & 5.5 & 4.6 & 5.3 & 0.9 \\
Yak & 16.8 & 5.2 & 4.6 & 7.0 & - \\
Donkey & 10.2 & 1.7 & 6.9 & 1.2 & 0.4 \\
Mare & 11.0 & 2.7 & 6.1 & 1.6 & 0.5 \\
\hline
\end{tabular}

The table is adapted and modified from (Park and Haenlein 2006) 
(BSA), and miscellaneous minor proteins. $\alpha$-lactalbumin is the most common constituent of whey protein which is found in the milk of all mammals and plays a major role in the synthesis of the milk sugar, lactose. $\beta$-lactoglobulin is the major whey protein found in the milk, however, it is not present in camel and human milk. $\beta$-lactoglobulin accounts for about $50 \%$ of the total whey proteins in ruminant milk and about 35\% in donkey and mare milk (Alichanidis et al. 2016). The NPN content in the milk of mammals is highly variable and it is influenced by breed, herd, lactation, seasons, and feeding practices. For instance, the NPN content in mare milk is around $10-15 \%$ of the total milk nitrogen content, in cow milk, it is $5 \%$, whereas in human milk it is about $25 \%$. Ruminant milk has about $3-5 \% \mathrm{NPN}$, and, sheep and goat have higher content than cow milk. The most dominant fraction in the NPN is urea, which can account for about $50 \%$ of the total nitrogen content of NPN. The next most abundant component is the free amino acids, which accounts for about 16\% in sheep milk, $10-20 \%$ in cow milk, and about $9-10.5 \%$ in goat milk. Taurine, citrulline, and ornithine, which are not a part of protein-bound amino acids, are also found in certain milk. Taurine is a growth modulator and membrane stabilizer and plays a significant role in the formation of bile acids. Taurine is the most abundant amino acid in goat milk followed by human milk. Table 2 gives a detailed comparative view of the protein composition profile of milk from different mammals.

\section{Bioactive peptides derived from milk of minor dairy species \\ Camel milk}

Camel milk has a special significance in human nutrition, particularly in hot and arid countries. The global production of camel milk is estimated to be 5.3 million tons, with Somalia being the major producer (Food and Agriculture Organization of the United Nations n.d.). Camel milk consists of four major types of caseins, namely, $\alpha s_{1}$-casein, $\alpha s_{2}$-casein, $\beta$-casein, and $\kappa$-casein. Among these, $\beta$-casein content was the highest (65\%), followed by $\alpha \mathrm{s}_{1}$-casein $(22 \%)$ and $\mathrm{k}$-casein (3\%) (Farrell et al. 2004). Furthermore, camel milk has been reported to be more susceptible to digestion with chymotrypsin, suggesting the fact that a large number of potential bioactive peptides could be generated from camel milk (Salami et al. 2008). The presence of such bioactive peptides from camel milk has been listed as follows:

Antioxidant peptides Hydrolysis of camel milk using pepsin-pancreatin enzymes yielded peptides with antioxidant and anti-cytotoxic activity (Homayouni-Tabrizi et al. 2017). Concentration and purification of the peptides were achieved through ultrafiltration and reverse phase liquid chromatography, respectively. Three peptides with sequences LEEQQQTEDEQQDQL (MW: 1860.85 Da, LL-15), YLEELHRLNAGY (MW: 1477.63 Da, YY-11), and RGLHPVPQ (MW: 903.04 Da, RQ-8) were obtained and exhibited high free radical scavenging activity and increased expression of dismutase and catalase genes in cell line. Ibrahim et al. (2018) fractionated camel milk proteins and hydrolyzed them separately using pepsin. Results revealed that antioxidant peptides with molecular weights between 913 to $2351 \mathrm{Da}$ were derived from $\alpha$-casein and lactoferrin, respectively, thus suggesting that both casein and whey proteins from camel milk have the potential for being utilized as an ingredient in nutraceuticals or functional foods. Kumar et al. (2016b) used commercial proteases namely papain, Alcalase and chymotrypsin to hydrolyze the casein

Table 2 Comparative protein composition profile from milk of minor dairy species (concentration range)

\begin{tabular}{|c|c|c|c|c|c|c|}
\hline Protein Fraction & Camel & Goat & Sheep & Yak & Donkey & Mare \\
\hline Total casein $(\mathrm{g} / \mathrm{kg})$ & $22-48$ & $23-38$ & $41-66$ & $21-40$ & $6-10$ & $8-14$ \\
\hline$a_{s} 1-$ Casein (\% total) & 21 & $4.5-34$ & $7-40$ & $13-32$ & - & $17-47$ \\
\hline$a_{s} 2-$ Casein (\% total) & 9 & $9-25$ & $12-23$ & $9-18$ & - & 2 \\
\hline$\beta$-Casein (\% total) & 65 & $34-64$ & $34-62$ & $37-51$ & - & $46-79$ \\
\hline к-Casein (\% total) & $3-5$ & $10-19$ & $7-23$ & $12-21$ & - & $2-8$ \\
\hline$\gamma$-Casein (\% total) & - & $5-6$ & - & - & - & - \\
\hline Total whey proteins $(\mathrm{g} / \mathrm{kg})$ & $6-10$ & $3-12$ & $8-16$ & 11 & $5-9$ & $7-10$ \\
\hline a-Lactalbumin (\% total WP) & $45-53$ & $17-50$ & $13-45$ & $7-20$ & $23-33$ & $17-42$ \\
\hline$\beta$-Lactoglobulin (\% total WP) & - & $34-77$ & $28-72$ & $50-86$ & $30-57$ & $17-50$ \\
\hline Serum albumin (\% total WP) & $30-41$ & $5-22$ & 6 & $7-15$ & $6-7$ & $3-5$ \\
\hline Immunoglobulins (g/kg) & $0.55-0.8$ & $0.15-0.5$ & $0.5-0.7$ & $0.1-0.4$ & 1.3 & $0.4-2.5$ \\
\hline Lactoferrin (g/kg) & $0.2-0.9$ & $0.02-0.3$ & $0.7-0.9$ & $0.2-0.7$ & 0.3 & $0.6-1.3$ \\
\hline NPN (\% total N) & $6-11$ & $7-12$ & $6-9$ & 6 & $11-25$ & $10-15$ \\
\hline
\end{tabular}

The table is adapted and modified from (Alichanidis et al. 2016) 
fraction of camel milk protein. It was found that the hydrolysate obtained by chymotrypsin had a higher antioxidant activity, while Alcalase and chymotrypsin both yielded peptides with comparable antimicrobial activity. They concluded that the whole milk protein hydrolysate could be more beneficial when used as a nutraceutical or functional food ingredient in comparison to hydrolysates of milk protein fractions. Jrad et al. (2014) had studied the antioxidant properties of camel milk casein hydrolysate using 2,2'-azino-bis(3-ethylbenzothiazoline-6-sulfonic acid (ABTS) radical cation and concluded that antioxidant activity of camel milk casein was much more efficient after digestion with pepsin and pancreatic enzymes. On similar lines, Kumar et al. (2016a) investigated the antioxidant activity of casein hydrolysate after hydrolysis by Alcalase and papain. They found that both the hydrolysates obtained exhibited a significant increase in 2,2-diphenyl-1-picrylhydrazyl (DPPH), Ferric Reducing Antioxidant Power (FRAP), and ABTS, with an increase in the duration of hydrolysis and degree of hydrolysis. Three novel antioxidant peptides have been isolated from Bactrians camel milk hydrolysate by Wali et al. (2020). All purified and sequenced peptides: RLDG QGRPRVWLGR (TFI-b1), MW: 1665.94; TPDNIDIW LGGIAEPQVKR (TFI-b2), MW: 2122.13, andVAYSDDGENWTEYRDQGAVEGK (TFI-b3), MW: 2489.09 exhibited very high antioxidant activity as free radical scavengers.

ACE inhibitory peptides Higher proline content in the structure of casein fraction of camel milk is reported to be a contributory factor for better ACE inhibitory and antioxidant activity of hydrolysates obtained from camel milk as compared to the milk from other species (Moslehishad et al. 2013). ACE inhibitory activity of camel milk hydrolysate obtained by in vitro gastrointestinal digestion was studied by Tagliazucchi et al. (2016). They studied the different fractions and found that the strongest ACE inhibitory activity was exhibited by the post-pancreatic $<3 \mathrm{kDa}$ fraction. Sequencing of these fractions yielded 17 peptides known to possess ACE inhibitory activity. In another study by Alhaj (2016), peptides possessing ACE inhibitory activity were identified from fermented camel milk of dromedary species. Camel milk was fermented with two potent bacterial cultures namely, L. helveticus and L. acidophilus. HPLC-MALDI-TOF analysis showed the presence of ten potent peptides exhibiting ACE-inhibitory activity. Camel milk fermented with $L$. heveticus yielded stronger ACE-inhibitory activity than other strains ( $L$. acidophilus). Results of this study also revealed that these peptides were stable up to 15 days of storage. Camel milk protein fractions, namely $\beta$-casein and whole casein, were also studied by Salami et al. (2010), and they evaluated the biological activity of these fractions. Results showed that the digestion with pepsin enhanced the ACE-inhibitory activity of the whole as well as $\beta$-casein. Therefore, camel milk was suggested to release innate peptides with antihypertensive properties. Mimicking the in vitro gastrointestinal digestion model for digestion of camel milk proteins (whey and casein), it was found that a higher ACE inhibitory activity was achieved following digestion with pepsin (Jrad et al. 2014). Moreover, camel colostrum also exhibited a higher ACE-inhibitory activity following digestion. The study identified 180 peptides with biological activities, out of which 25 peptides were known to be associated with ACE-inhibitory activity. Shuangquan et al. (2008) had also studied the ACE inhibitory activity of fermented skim camel milk. Fermentation of skim camel milk was achieved by culturing with $L$. helveticus 130 B4. Peptide sequences exhibiting the strongest antihypertensive activity were derived from $\mathrm{k}$-casein and it was also demonstrated that inhibitory activity was quite stable after treatment at $100{ }^{\circ} \mathrm{C}$ for $20 \mathrm{~min}$. Rahimi et al. (2016) had used proteinase $\mathrm{K}$ for the evaluation of ACE inhibitory activity of camel milk casein hydrolysate and results recommended the use of whole camel casein as a substrate for the production of peptides with antihypertensive properties. Soleymanzadeh et al. (2019) had identified a novel ACE inhibitory peptide from fermented camel milk (Leuconostoc lactis). Less than $3 \mathrm{kDa}$ ultra filtered fraction with biologically active peptide (MVPYPQR) exhibited ACEinhibitory activity with $\mathrm{IC}_{50}$ value of $1.61 \pm 0.18 \mathrm{mg} / \mathrm{mL}$.

Anti-diabetic and Anti-obesity peptides Novel antidiabetic and anti-obesity peptides (KDLWDDFKGL, MPSKPPLL) were obtained in the hydrolysates of camel milk protein in a study by Mudgil et al. (2018). Nongonierma et al. (2017) identified anti-diabetic peptides with dipeptidyl peptidase 4 (DPP-IV) inhibitory activity, in camel milk protein hydrolysates. Results revealed the presence of potential and novel DPP-IV inhibitory peptides (Leu-Pro-Val-Pro-Gln and Trp-Lys) which were reported to be absent in bovine milk hydrolysates. This indicated the unexplored potential of camel milk as a substrate for diabetes management. Also, Nongonierma et al. (2018) identified nine novel peptides possessing DPP-IV inhibitory activity (FLQY, FQLGASPY, ILDKEGIDY, ILELA, LLQLEAIR, LPVP, LQALHQGQIV, MPVQA, and SPVVPF) upon the hydrolysis of camel milk protein with trypsin. Thus, camel milk was reported to be an important commodity having a role in glycemia regulation. Cholesterol esterase has been reported to be associated with the development of obesity and other related complications. Thus, in an interesting study conducted by Mudgil et al. (2019), novel peptides were isolated from camel milk protein hydrolysate and then evaluated for their inhibition of cholesterol esterase. Results revealed that hydrolysate 
obtained by the digestion with papain exhibited the highest degree of hydrolysis. Peptide identification showed three peptides with sequences KFQWGY, SQDWSFY, and YWYPPQ, exhibiting high affinity towards the binding site of cholesterol esterase.

Antimicrobial peptides In a study by Algboory and Muhialdin (2018), protein hydrolysates found in fermented camel milk produced using Lactobacillus plantarum, exhibited antimicrobial activity against Staphylococcus sp., Shigella, and E. coli. One of the fractions, out of the 14 isolated, yielded 32 low molecular weight peptides and exhibited the strongest antimicrobial activity. This study suggested the utilization of L. plantarum as a suitable starter culture for the production of antimicrobial peptides in camel milk-based functional products. Jrad et al. (2014) investigated the antimicrobial properties of camel colostrum as well as camel milk proteins and demonstrated that colostrum and milk both had an inhibitory effect on the growth of E.coli and L. innocua. They also showed that the antimicrobial effect was significant even before the digestion of the sample, however, it became pronounced after the samples were subjected to gastric and intestinal proteolytic enzymes. Abu-qatouseh (2019) derived immune proteins and peptides from camel milk and evaluated their efficacy against Propionibacterium acnes. It was shown that peptidoglycan recognition proteins exhibited the strongest antimicrobial activity as compared to lactoferrin. Thus, camel milk was suggested to be utilized for the treatment of Acne vulgaris.

\section{Goat milk}

Goat milk has been extensively studied and characterized for their bioactive peptides. They also contain the four main fractions of caseins ( $\alpha \mathrm{s}_{1}$-casein, $\alpha \mathrm{s}_{2}$-casein, $\beta$ casein, and $\mathrm{k}$-casein), however, goat casein has been found to undergo a broad range of post-translational modifications leading to the production of a wide variety of the casein molecule (Marletta et al. 2007). Goat milk whey proteins primarily consist of $\alpha$-lactalbumin and $\beta$ lactoglobulin, the latter being significantly higher in concentration than cow's milk (Moatsou et al. 2005). Various bioactive peptides have been reported to be produced from goat milk and milk products in the past decades. Some of those beneficial properties are reported here as follows:

Antioxidant peptides Fermented goat milk has shown the presence of antioxidant peptides more often. In this regard, Lactobacillus casei L61 was used to ferment the goat milk and the milk was further subjected to isolation and purification of antioxidant peptides (Shu et al. 2018). They proved that these antioxidant peptides were quite stable during simulated in vitro digestibility experiment. Commercial proteases namely, subtilisin and trypsin, were used to produce goat milk microfiltration hydrolysate (De Gobba et al. 2014). It was found that the retentate generated with subtilisin hydrolysis, showed the highest radical scavenging activity, whereas, the permeate had a high iron chelation capacity and formed a large number of secondary lipid oxidation products. The role of non-protein compounds in permeate was highlighted more than the antioxidant activity related peptides. Similarly, antioxidant peptides were identified in goat milk protein fractions by Ahmed et al. (2015). Goat milk proteins were fractionated into casein and whey, which were further digested using pepsin. Peptides generated showed potent DPPH and superoxide quenching activity. MALDI-TOF-MS was further used to identify these peptides and it was found that $\beta$-casein and $\beta$ lactoglobulin were the major contributors to these antioxidant bioactive peptides. In a study by Li et al. (2013), antioxidant peptides were purified and identified from casein protein fraction of goat milk. Neutral and alkaline proteases were used to produce goat milk casein hydrolysate. They found a significant increase in free radical scavenging and iron chelation capacities with goat milk protein hydrolysate which was attributed to five novel oligopeptides, namely Val-Tyr-Pro-Phe, Phe-Gly-Gly-Met-Ala-His, Phe-Pro-Tyr-Cys-Ala-Pro, Tyr-Val-Pro-Glu-Pro-Phe, and Tyr-Pro-Pro-Tyr-Glu-Thr-Tyr. Antioxidant activity of these peptides were 3.60 to 3.80 times higher than the goat milk casein.

ACE inhibitory peptides ACE inhibitory peptides have an immense role in lowering blood pressure or to combat hypertension. Commercial proteases have been studied for ACE inhibitory peptide production from goat milk by Bao et al. (2016). Alcalase was found to be the best enzyme for the production of ACE-inhibitory peptides with $95.31 \%$ activity. In another study by Geerlings et al. (2006), subtilisin and Alcalase were used to identify and characterize ACE inhibitory peptides from goat milk. They isolated three novel ACE inhibitory peptides namely, TGPIPN, SLPQ, and SQPK, with inhibitory concentrations of 316,330 and $354 \mu \mathrm{mol} / \mathrm{L}$, respectively. In the same study, the efficacy of the goat milk protein hydrolysate was evaluated using in vivo models and it was found that the long-term administration of goat milk protein hydrolysate reduced the occurrence of hypertension, cardiac and renal hypertrophy, and renal dysfunction. Espejo-Carpio et al. (2014) produced ACE inhibitory peptides from ultra-filtered goat milk protein hydrolysates (casein fractions). Treatment of ultra-filtered goat milk casein with subtilisin and trypsin exhibited relatively higher ACE inhibitory activity. Besides commercial proteases, purified proteinase has also been studied for its efficacy in 
the production of peptides. One such study employed partially purified proteinases of Lactobacillus helveticus PR4 and the hydrolysate was subjected to reversed phase fast protein liquid chromatography for peptide fractionation (Minervini et al. 2003). Fractions with the highest ACE inhibitory activity ( $\beta-C N$ f5865 and $\alpha \mathrm{S} 2-\mathrm{CN}$ f182-187) were sequenced by mass spectroscopy. Corresponding sequences obtained were LVYPFPGP and TVDQHQ with monoisotopic mass of 888.47 Da and 727.33 Da, respectively.

Bacterial cultures have also been used for the production of ACE inhibitory peptides. Chen et al. (2018) used Lactobacillus plantarum 69 to ferment goat milk and evaluate its potential to generate ACE inhibitory peptides. The generated hydrolysate exhibited $88.91 \%$ ACE inhibitory activity; however, when it was further purified by ultrafiltration and RP-HPLC, it showed an ACE inhibitory activity of $91.62 \%$. Another study conducted by Shu et al. (2017) utilized Lactobacillus bulgaricusLB6 for the fermentation of goat milk to increase antihypertensive activity. Results showed an increase in ACE inhibitory activity by $10 \%$ (from $75 \%$ to around $84.6 \%$ ). Ibrahim et al. (2017) evaluated the presence of ACE inhibitory peptides separately in casein and whey fractions of goat milk. They found that pepsin generated hydrolysates of whey and casein demonstrated significantly higher ACE inhibitory activities as compared to the undigested proteins. Furthermore, they identified three potent ACE inhibitory peptides namely, PEQSLACQCL from $\beta$-lactoglobulin (residues 113-122), QSLVYP FTGPI from $\beta$-casein (residues 56-66), and ARHPHPHL SFM from $\mathrm{k}$-casein (residues 96-106), which exhibited significantly higher ACE inhibitory activity than a commercial antihypertensive drug, captopril. In another study conducted by Aslam et al. (2018), goat milk proteins were fermented with Lactobacillus helveticus -cicc 22,171 and further hydrolyzed to elucidate the structure and amino acid sequences with mass spectrometry. The results revealed that the peptides, VLPVPQKAVPQ and VLPVPQKVVPQ containing PVP and VVP, exhibited the highest ACE inhibitory activity owing to their higher concentration of hydrophobic and aromatic amino acids.

Anti-diabetic peptides Bioactive peptides involved in reducing the blood glucose levels were isolated from goat milk hydrolysate using liquid chromatography-mass spectrometry technique by Gong et al. (2020). Identified bioactive peptides were SDIPNPIGSE ( $\alpha$ S1-casein, f195204), NPWDQVKR $(\alpha$ S2-casein, f123-130), SLSSSEES ITH ( $\beta$-casein, f30-40), and QEPVLGPVRGPFP ( $\beta$-casein, f207-219). These peptides improved insulin resistance in HepG2 cells when treated with high glucose. Zhang et al. (2015) isolated and identified novel DPP-IV inhibitory peptides namely, MHQPPQPL, SPTVMFPP
QSVL, VMFPPQSVL, and INNQFLPYPY, after treating the goat milk casein with trypsin and chymotrypsin. They have used two-dimensional silica-thin layer chromatography technique for their isolation and identification.

Antimicrobial peptides The commercial protease, Alcalase, was used to hydrolyze whey protein fraction of goat milk (Osman et al. 2016). Fractions with the highest degree of hydrolysis were fractionated further and evaluated for their antibacterial activity by disc diffusion method. Fractions eluted by size exclusion chromatography showed antibacterial activity against E.coli with a minimum inhibitory concentration (MIC) of $0.09 \mathrm{mg} /$ $\mathrm{mL}$ and against B.cereus (MIC: $0.03 \mathrm{mg} / \mathrm{mL}$ ). The study concluded with the potential of goat milk whey hydrolysate to control undesirable bacteria in food products. Fungal proteases, from Aspergillus oryzae and Aspergillus flavipes, have also been used to hydrolyze goat milk, which was further evaluated for their potential role in antimicrobial activity (Zanutto-Elgui et al. 2019). Results revealed that the generated peptides exhibited antimicrobial activity against all tested bacteria and fungi. Goat milk whey fraction has also been evaluated for its antifungal and antimycotoxigenic activity on Penicilliumspp (Luz et al. 2020). Twenty seven peptides were identified from $\alpha$-lactalbumin, $\beta$-lactoglobulin, $\kappa$-casein and lactoferrin, which exhibited fungal growth inhibition and Minimum Inhibitory Concentration (MIC) of 3.9$62.5 \mathrm{~g}$ hydrolysate/L. In another study by Lestari and Suyata (2019), goat milk from Etawa breed was hydrolysed with crude extract of bromelain enzyme (from pineapple). The hydrolysate was tested for its antibacterial activity (against E. coli and S. aureus) and the results demonstrated significantly higher antibacterial activity compared to the non-digested control. Similarly, Esmaeilpour et al. (2016) used trypsin and ficin enzymes to evaluate the efficacy of goat milk casein hydrolysate and reported that one of the fractions (F14) possessed a very high antibacterial activity against E.coli and B.cereus.

\section{Sheep}

Sheep milk consists of high protein content (around $5.8 \%$ on average), however, this varies among different breeds of sheep, usually influenced by genetic and environmental factors (Recio et al. 2009). Sheep milk protein is characterized by $76-83 \%$ of total casein and $17-24 \%$ of total whey proteins (Moatsou et al. 2005). The casein protein is further relatively distributed as $12-16.4 \%$ of $\alpha_{\mathrm{s} 2}$-casein, $33.9-39.9 \%$ of $\alpha_{\mathrm{s} 1}$-casein, $37-42.3 \%$ of $\beta$ casein, and 9.1-10.8\% of $\kappa$-casein (Moatsou et al. 2004). Sheep milk protein hydrolysates have been shown to possess multiple health beneficial factors as follows: 
Antioxidant peptides Hydrolysis of sheep milk sodium caseinate with Bacillus sp. P7 protease generated peptides with an antioxidant activity which was higher than the intact protein (Corrêa et al. 2011). Sequential hydrolysis of the sheep casein protein with pepsin, trypsin, and chymotrypsin produced hydrolysates with high antioxidant activity, and this effect was more pronounced with $\mathrm{K}$-casein. The most potent peptide found in the $\kappa$-casein hydrolysate was HPHPHLSF, among eleven other peptides identified, showing the antioxidant activity. The isolated peptide HPHPHLSF demonstrated lipid peroxidation inhibition activity similar to the synthetic antioxidant Butylated hydroxytoluene (BHT). The strong antioxidant activity of the peptide was mainly attributed to the presence of high histidine and leucine content in the peptide sequence, which is known for its oxidation inhibition properties. Besides, even proline has been known for its antioxidant properties. Thus, the peptide HPHPHL SF could potentially be used as a natural antioxidant replacing the synthetic ones (Gómez-Ruiz et al. 2008).

ACE inhibitory peptides ACE inhibitory peptides were generated from sheep sodium caseinate hydrolysis via Bacillus sp. P7 protease. However, $2 \mathrm{~h}$ hydrolysis produced the most active peptides while an increase in the hydrolysis time decreased the ACE inhibitory activity (Corrêa et al. 2011). Sheep casein hydrolyzed by Lactobacillus helveticusPR4 proteinase generated ACE inhibitory peptides derived from $\alpha_{\mathrm{s} 2}$-casein (residues 182-185) and $\alpha_{\mathrm{s} 1}$-casein (residues 1-6) (Minervini et al. 2003). Trypsin hydrolysis of sheep $\beta$-lactoglobulin (both $\mathrm{A}$ and $B$ variants mixture) generated ACE inhibitory peptides from the N-terminal of the protein. Among those peptides, the more hydrophilic ones were shown to possess higher ACE inhibitory activity (Recio et al. 2009).

Antimicrobial peptides Bacillus sp. P7 derived protease hydrolysis of sheep caseinate produced hydrolysates which demonstrated antimicrobial activities against Corynebacterium fimi, Bacillus cereus, Aspergillus fumigatus, and Penicillium expansum (Corrêa et al. 2011). Peptic hydrolysis of the $\alpha s 2$-casein generated four antibacterial peptides from the casein protein corresponding to the amino acid residues 165-181 (LKKISQYYQKFAWPQY L),165-170 (LKKISQ), 203-208 (PYVRYL), and 184208 (VDQHQKAMKPWTQPKTNAIPYVRYL). These peptides were shown to be effective against various Gram-positive and Gram-negative bacteria. Among the four peptides, the most potent one was derived from amino acids 165-180 (López-Expósito et al. 2006). Sheep $\alpha$-lactalbumin and $\beta$-lactoglobulin hydrolysis with pepsin generated hydrolysates capable of exhibiting dosedependent antibacterial activity against Bacillus subtilis,
Escherichia coli, and Staphylococcus aureus (Elzahar et al. 2004).

Antithrombic peptides Sheep casein glycomacropeptide (CMP) has been demonstrated to possess antiplatelet aggregation properties and this activity was further shown to increase with trypsin hydrolysis. Trypsin hydrolysis of sheep CMP released two peptides derived from K-casein (amino acids 163-171 and 165-171) which had high antithrombotic activities (Qian et al. 1995).

\section{Yak}

Yak milk consists of high protein content $(46.2-58.4 \mathrm{~g} /$ L) out of which casein constitutes almost about $40.2 \mathrm{~g} / \mathrm{L}$ on an average. It is also rich in milk fat (6.7\%) and nonfat solids (11\%). Yak milk products are a major ingredient in the Mongolian indigenous diet (Ochirkhuyag et al. 1997).

In a study by Jiang et al. (2007), yak milk casein was hydrolyzed by six different protease enzymes. The hydrolysates with the highest ACE inhibitory activity were obtained from the hydrolysis with Neutrase enzyme with an $\mathrm{IC}_{50}$ value of $0.38 \mathrm{mg} / \mathrm{mL}$. Five peptides were identified from this hydrolysate which were shown to possess the ACE inhibitory activity: LQNIPPL ( $\beta$-casein, residues $70-77)$, YQKFPQY $\left(\alpha_{\mathrm{s} 2}\right.$-casein, residues $\left.89-95\right)$, LPYP YY ( $\kappa$-casein, residues 56-61), SKVLPVPQK ( $\beta$-casein, residues 168-176), and FLPYPYY ( $\mathrm{K}$-casein, residues5561). All these five peptides were identical with peptides found in cow's milk casein and possessed ACEinhibitory activities. Furthermore, for four out of the five peptides, the C-terminus was occupied by a hydrophobic amino acid, which is a characteristic feature of known ACE inhibitory peptides (Jiang et al. 2007).

In a study by Mao et al. (2007a, 2007b), hydrolysates obtained via Alcalase hydrolysis of yak milk casein were shown to modulate the differentiation of $\mathrm{T}$-helper cells (Th) along with shifting the Th1/Th2 balance towards Th1-dominant phenotype. Thus, it was suggested that yak milk-derived hydrolysates could potentially help in cell-mediated immune diseases (Mao et al. 2007a, 2007b). The Alcalase derived hydrolysates were also found to suppress tumor cells (Mao et al. 2005). In another study, which tested the role of several different enzymes as well as different hydrolysis times in the generation of bioactive hydrolysates, it was shown that yak casein hydrolysates obtained from trypsin and Alcalase hydrolysis yielded peptides with higher DPPHscavenging activities, as compared to flavozyme, papain, and peptic hydrolysates. Furthermore, the $7 \mathrm{~h}$ long hydrolysis with Alcalase had the highest DPPH-scavenging activity, compared to shorter hydrolysis periods (Mao et al. 2011). 
Alcalase hydrolysis of the yak milk casein also led to the generation of ACE inhibitory hydrolysates. The hydrolysate was further separated into different molecularsized fractions via membrane ultrafiltration. The highest ACE inhibitory activity was shown by the $6 \mathrm{Da}$ fractions amongst all the other fractions of the hydrolysate. Two novel peptides involved in the ACE inhibitory activity were identified in the $6 \mathrm{Da}$ fractions, which were, PLPLL ( $\beta$-casein, amino acid residues 136-140) and PPEIN ( $\kappa-$ casein, amino acid residues $156-160$ ). The $\mathrm{IC}_{50}$ and molecular weight of the two peptides were 566.4 and 550 $\mathrm{Da}$, and $0.25 \pm 0.01$ and $0.29 \pm 0.01 \mathrm{mg} / \mathrm{mL}$, respectively (Mao et al. 2007a, 2007b).

Alcalase derived yak casein hydrolysates have also been shown to possess immunomodulatory and antioxidant activities, as the hydrolysates have been effective in reducing the expressions of pro-inflammatory cytokines such as tumor necrosis factor-alpha (TNF- $\alpha$ ), interleukin-1 $\beta$ (IL$1 \beta$ ), and IL-6, as well as reducing free radicals of DPPH, hydrogen peroxide, and superoxide (Wang et al. 2011). However, the peptides in these hydrolysates have not been separated and characterized. Moreover, Wang et al. showed that yak casein hydrolysates were capable of mineral binding as they could bind ferrous and zinc ions to form soluble complexes in simulated intestinal conditions (Wang et al. 2011). The major binding sites consisted of amide and carboxylate groups; however, specific peptides have not been identified yet.

In a study by Pei et al. (2017), waste yak milk, produced as a by-product during production of yak butter, was hydrolyzed by pepsin, and the hydrolysates produced were found to possess antimicrobial activity. On further purification and analysis, two peptides were identified in the hydrolysate responsible for the antimicrobial activity, namely, RVMFKWA and KVISMI. These peptides exhibited antimicrobial activities against bacteria such as E. coli, Listeria innocua, Salmonella paratyphi, and Enterobacter cloacae, as well as against certain fungi (Pei et al. 2017).

Another recent study by Lin et al. (2018) highlights an in silico proteolysis approach for the release of bioactive peptides with ACE-inhibitory activity from yak milk casein, using single or combined enzymes. The study identified several peptides with ACE inhibitory properties such as LPLPLL, KYIPIQ, and PFPGPIPN. Furthermore, their cytotoxicity was also determined through ToxinPred (online toxin prediction tool), to find that the peptides identified were non-toxic (Lin et al. 2018). This study could potentially serve as a guide for the actual yak milk protein hydrolysis and the identification of bioactive peptides.

\section{Mare}

Mare's (Equine) milk has been long used for its unique therapeutic and nutritive values in the southern states of former Soviet Union and Mongolia, which is currently also gaining acclamations in parts of Europe (Sheng and Fang 2009). Fermented mare milk, also known as Koumiss, has been used as a curative for cardiovascular and digestive disorders in Mongolia and Russia (Lozovich 1995).

Some of the qualitative and quantitative characteristics of mare milk which has been reported (Miranda et al. 2004; Uniacke-Lowe et al. 2010) are as follows:

- Mare milk contains about $2.7 \%$ of total proteins, out of which $55 \%$ is casein, while the rest is composed of $\beta$-lactoglobulin, $\alpha$-lactalbumin, whey proteins, immunoglobulins, and lysozyme.

- Proteins in mare milk are rapidly hydrolyzed by human gastrointestinal enzymes as compared to other popular milk proteins such as cow, camel, goat, and human milk proteins.

- Casein fraction of mare milk is considerably made up of $\beta$-casein, followed by $\alpha_{\mathrm{s} 1}$-casein, $\alpha_{\mathrm{s} 2}$-casein, and $\mathrm{k}$-casein.

- The $\alpha_{\mathrm{s} 1}$-casein in mare milk is composed of 205 amino acids with 6 phosphorylation sites, and 5 of those sites are so close to each other that they are considered as a probable source of bioactive peptides.

- The $\beta$-casein of mare milk consists of 226 amino acids with 7 potential phosphorylation sites at the C-terminal.

Although very limited research is available on the bioactive peptides released from mare milk, koumiss (fermented mare milk) has been reported to have ACE inhibitory activity $\left(\mathrm{IC}_{50} 52.5 \pm 2.9 \mathrm{mg} / \mathrm{mL}\right)$. The ACE inhibitors found in koumiss are reported to be true inhibitors or the prodrug type inhibitors, based on the hydrolysis pattern of the gastrointestinal enzymes (Chen et al. 2010). The fraction with the highest ACEinhibitory activity $\left(\mathrm{IC}_{50} 80.11 \pm 2.13 \mathrm{mg} / \mathrm{mL}\right)$ was $<3 \mathrm{kDa}$ in molecular weight and 21 peptides were separated from the fraction which showed variable ACE-inhibitory activity. There were 4 most potent peptides identified with ACE-inhibitory activity among 21 other peptides. The only ACE-inhibitory peptide found in koumiss was derived from the peptide P1 ( $\beta$-casein, amino acids 217241) (Chen et al. 2010). Protein P2 originated from cytochrome c, whereas proteins P3 and P4 were of unknown origin, probably of microbial origin. The unique feature of P1 ACE-inhibitory peptide is its length, which is 27 amino acids residues long, but still possesses high ACEinhibitory activity. In general, such high activities are a characteristic of smaller peptides (2-10 amino acid residues) (Ricci et al. 2010).

In another study by Kusumaningtyas et al. (2018), hydrolysis of the Sumbawa mare milk protein via Bacillus 
thuringenesis protease yielded hydrolysates capable of exhibiting antibacterial and antioxidant activities. The peptide fraction which was $<3 \mathrm{kDa}$ in molecular size, obtained from a $30 \mathrm{~min}$ hydrolysis, was shown to be the most potent antibacterial fraction and more effective against Gram-negative bacteria. The peptide identified was HPYFYAPELLYYANK (Kusumaningtyas et al. 2018).

\section{Donkey milk}

The increasing interest of consumers and researchers towards donkey milk is due to its similarity to human milk which paves the way for new avenues regarding its utilization as a functional ingredient or consumption as liquid food. It is reported to possess many health virtues owing to its antimicrobial, anti-inflammatory, antibacterial and anti-carcinogenic properties (Martini et al. 2018). Miao et al. (2020) had studied the effect of different processing conditions and fermentation characteristics of donkey milk and concluded that a higher peptide content was obtained upon its fermentation with L.helveticus LZ-R-5 and L. helveticus. On the other hand, digestion of donkey milk with pepsin and a mixture of pancreatic enzymes yielded 46 peptides, among which 30 peptides were from $\beta$-casein fraction of the milk (Bidasolo et al. 2012). They established the ACE inhibitory activity of the peptide ( $\beta-\mathrm{CN}$ fragment $\mathrm{f}(176-185)$ [VAPFPQPVVP]) with an $\mathrm{IC}_{50}$ of $48.8 \pm 2.3 \mathrm{mM}$. Piovesana et al. (2015) performed peptidome characterization of donkey milk and purified various peptides. Peptides were then analyzed for their bioactivities which showed $35 \%$ antioxidant activity and 67\% ACE inhibitory activity. Another peptide, TKTEEGEFISEGGGVR, was reported by the same authors, which was reportedly a fibrinopeptide, and had a role in haemostasis. In another study by Aspri et al. (2018), fermented goat milk samples were subjected to in vitro gastrointestinal digestion followed by analysis of digesta for ACE inhibitory activity. The results revealed that Enterococcus faecum DM33 fermented milk yielded peptides from casein and whey fractions which depicted the strongest antioxidant and antimicrobial activities, while donkey milk fermented with Lactobacillus casei DM214 revealed the highest ACE inhibitory activity. Antioxidant and ACE inhibitory activity exhibiting peptides were also isolated and purified from donkey milk by Zenezini Chiozzi et al. (2016), which were, namely, EWFTFLKEAGQGAKDMWR, GQGAKDMWR, and REWFTFLK, MPFLKSPIVPF respectively. Tidona et al. (2011) had evaluated the in vitro digestibility of donkey milk with gastric pepsin and duodenal juice containing various pancreatic enzymes. Digested samples exhibited significant antimicrobial activity against $E$. coli but not against $B$. cereus. Furthermore, dose-dependent inhibition of
Listeria monocytogens was also observed with digested donkey's milk (Table 3).

\section{Bioactive peptides derived from milk products of minor dairy species}

Milk based products hold an important role in the daily diet of people worldwide. Rearing of minor dairy species for production of milk is limited; however different dairy products are being manufactured to meet the local requirements. Fermentation based dairy products like cheese, fermented milk, yoghurt are highly popular. The data related to their preparation and physico-chemical properties are widely available due to the rapidly increasing interest in these products. However, limited studies have been carried out on bioactive properties of dairy products obtained from minor dairy species (Table 4).

\section{Cheese}

The type and concentration of bioactive peptides in cheeses may vary with thermal treatment of milk, type of starter, manufacturing conditions, ripening stage, curd scalding temperature, ripening stage, and rennet origin (Kocak et al. 2020; Meira et al. 2012; Silva et al. 2006). Among minor species, sheep and goat milk were widely explored for preparation of different varieties of cheeses.

$\beta$-casein-hydrolyzed fragments $\mathrm{f}(201-204)$ (VRGP), $\mathrm{f}(47-51)$ (DKIHP), and $\mathrm{f}(47-52)$ (DKIHPF), in 60 days old Spanish goat milk cheese, possessed ACE inhibitory activity (Gómez-Ruiz et al. 2006). In freeze-dried watersoluble extracts of sheep and goat milk cheese peptide, sequences VPKVK, YQEP, and YQEPVLGP, from native $\beta$-casein exhibited antioxidant and ACE inhibitory activity with higher extent of bioactivity in goat milk cheese (Silva et al. 2006). In goat milk cheese, ethanol soluble and insoluble nitrogen fractions showed ACE inhibitory activity owing to the small and medium sized peptides. Similarly, acid soluble and non-protein nitrogen fractions, consisting of medium and short chain peptides, possessed antioxidant activity (Hernández-Galán et al. 2017). Water soluble extracts of goat milk-based Tulum cheese, not only showed antioxidant activity and iron chelating ability, but also exhibited antimicrobial activity against Salmonella typhimurium ATCC 14028 on the 90th day of ripening (Öztürk and Akin 2018). The incorporation of adjunct cultures (Lactobacillus casei, Lactobacillus plantarum and Lactobacillus bulgaricus) with a starter mix (Lactococcus lactis subps lactis and Lactococcus lactis subspcremoris), for the preparation of goat milk brined cheese, contributed to the higher concentration of ACE inhibitory and antioxidant activity peptides along with other water-soluble nitrogenous compounds. These differences could be attributed to strain-dependent peptidase activity of adjuncts. However, all the samples, irrespective of type of culture mix, 


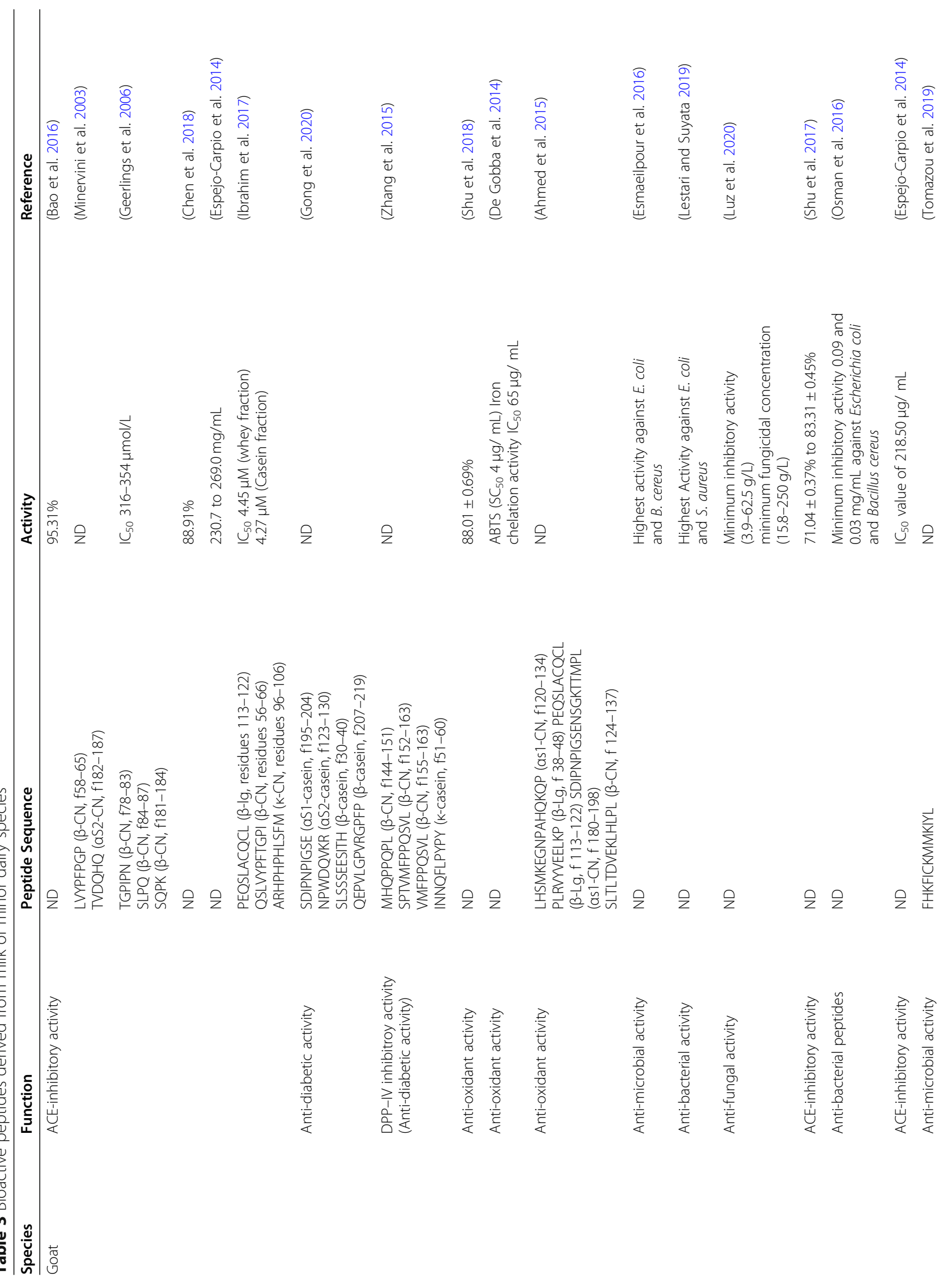




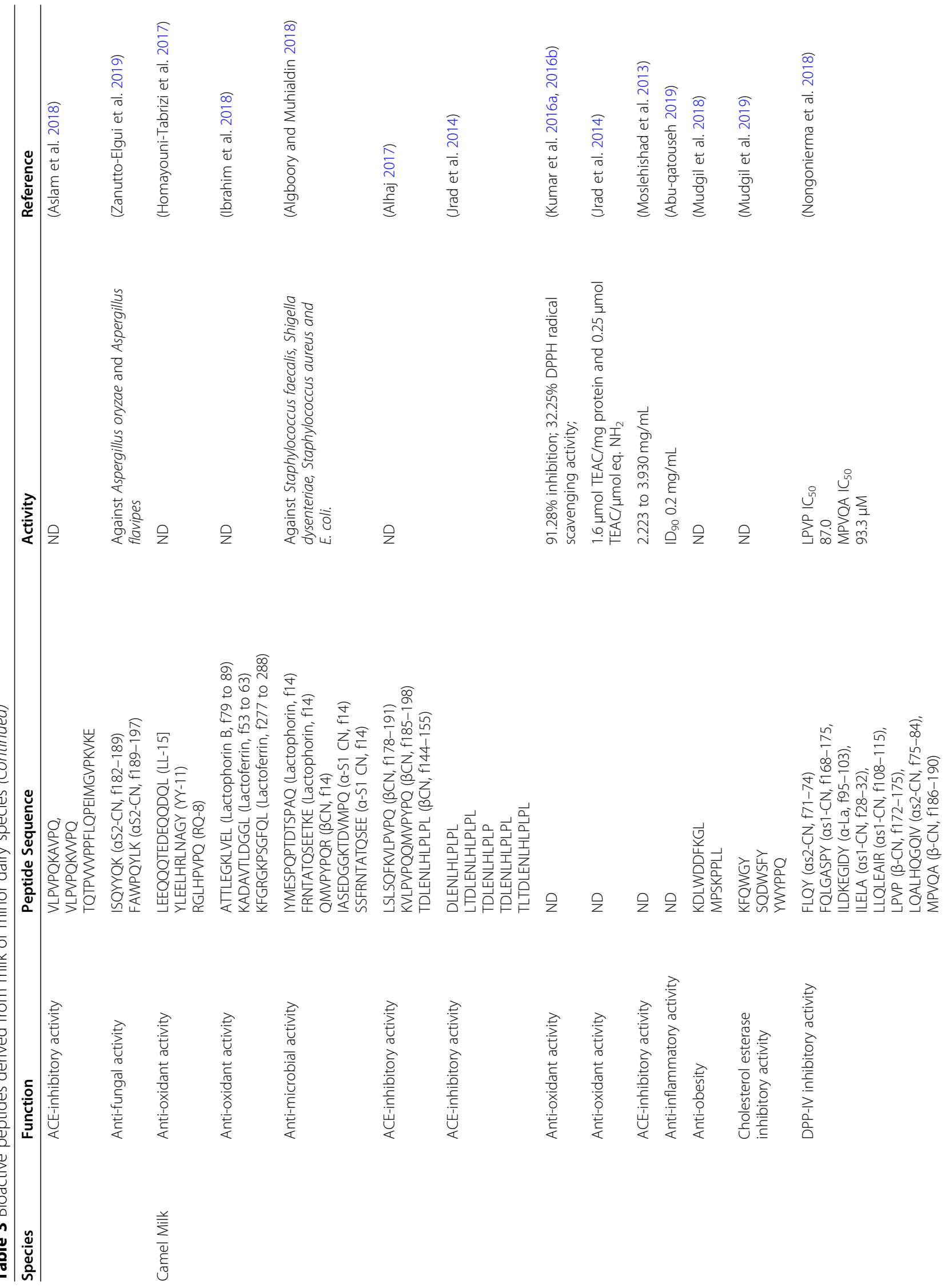




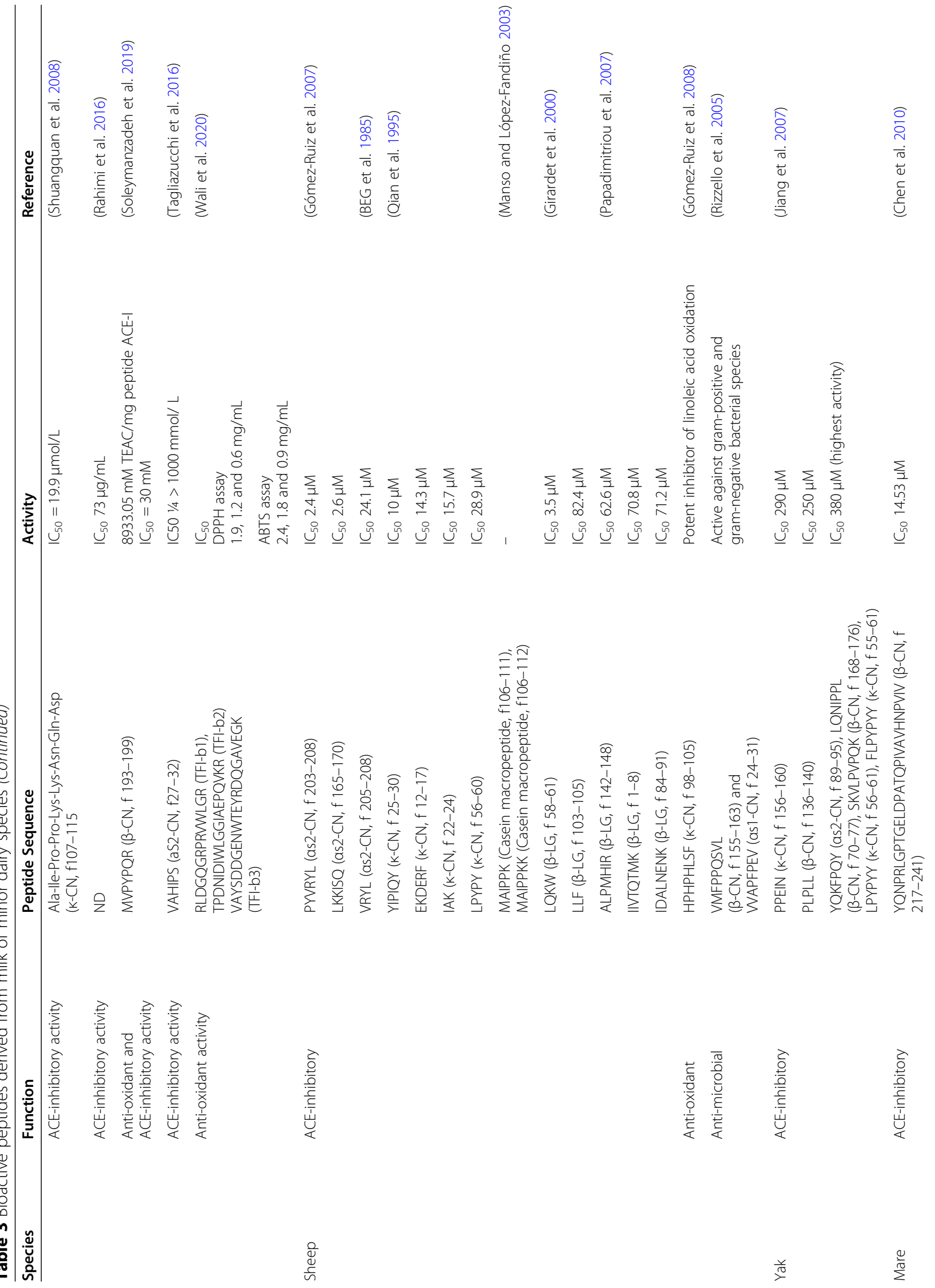




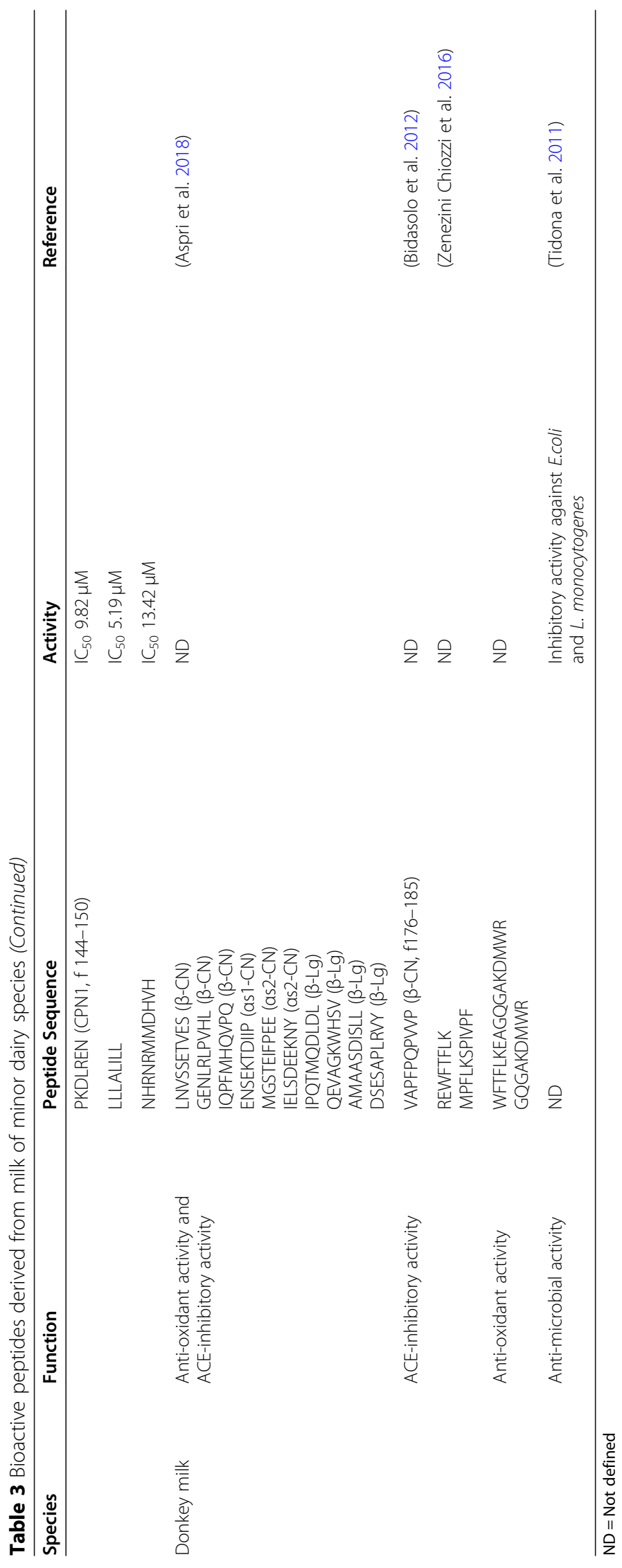




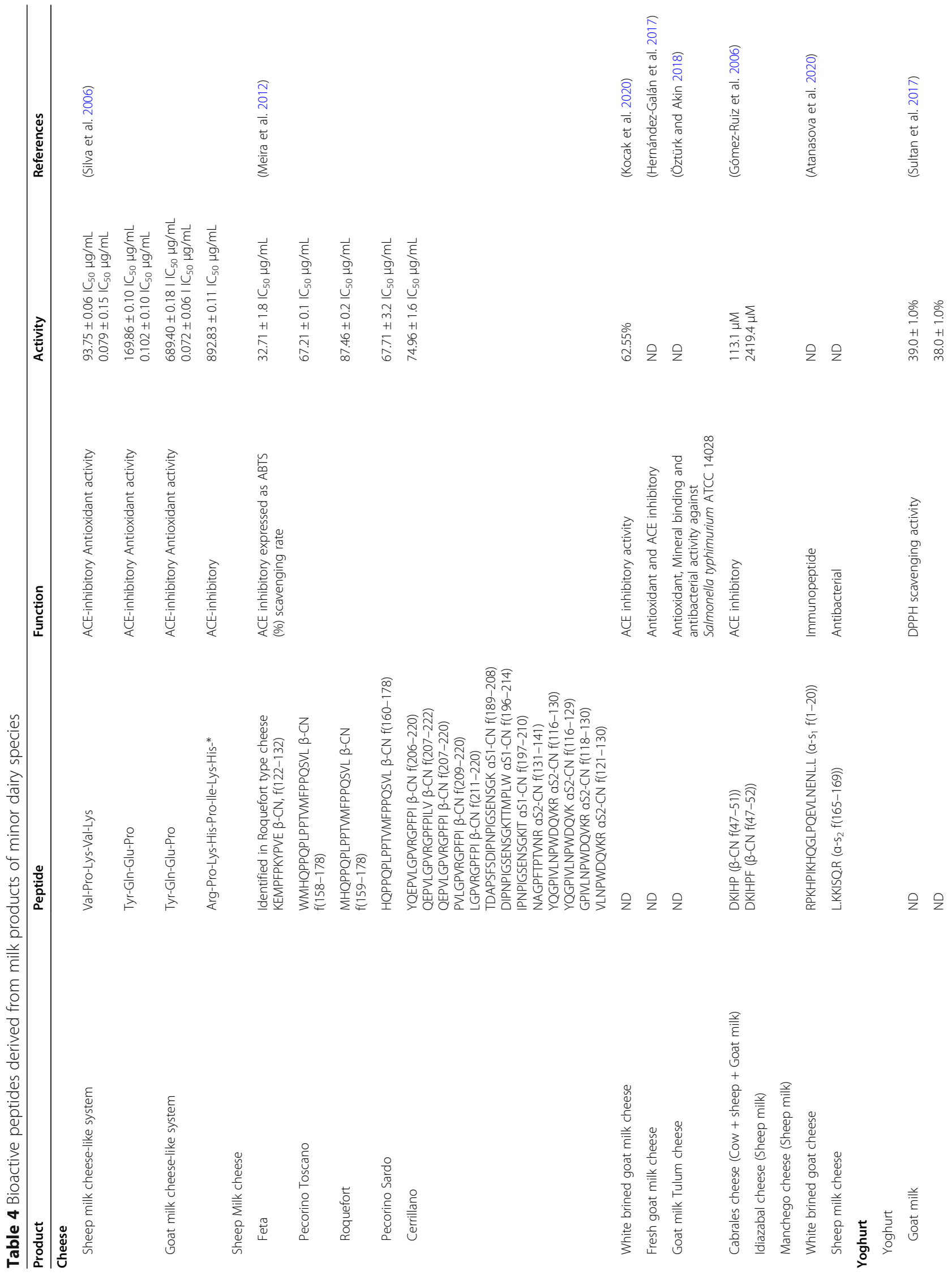




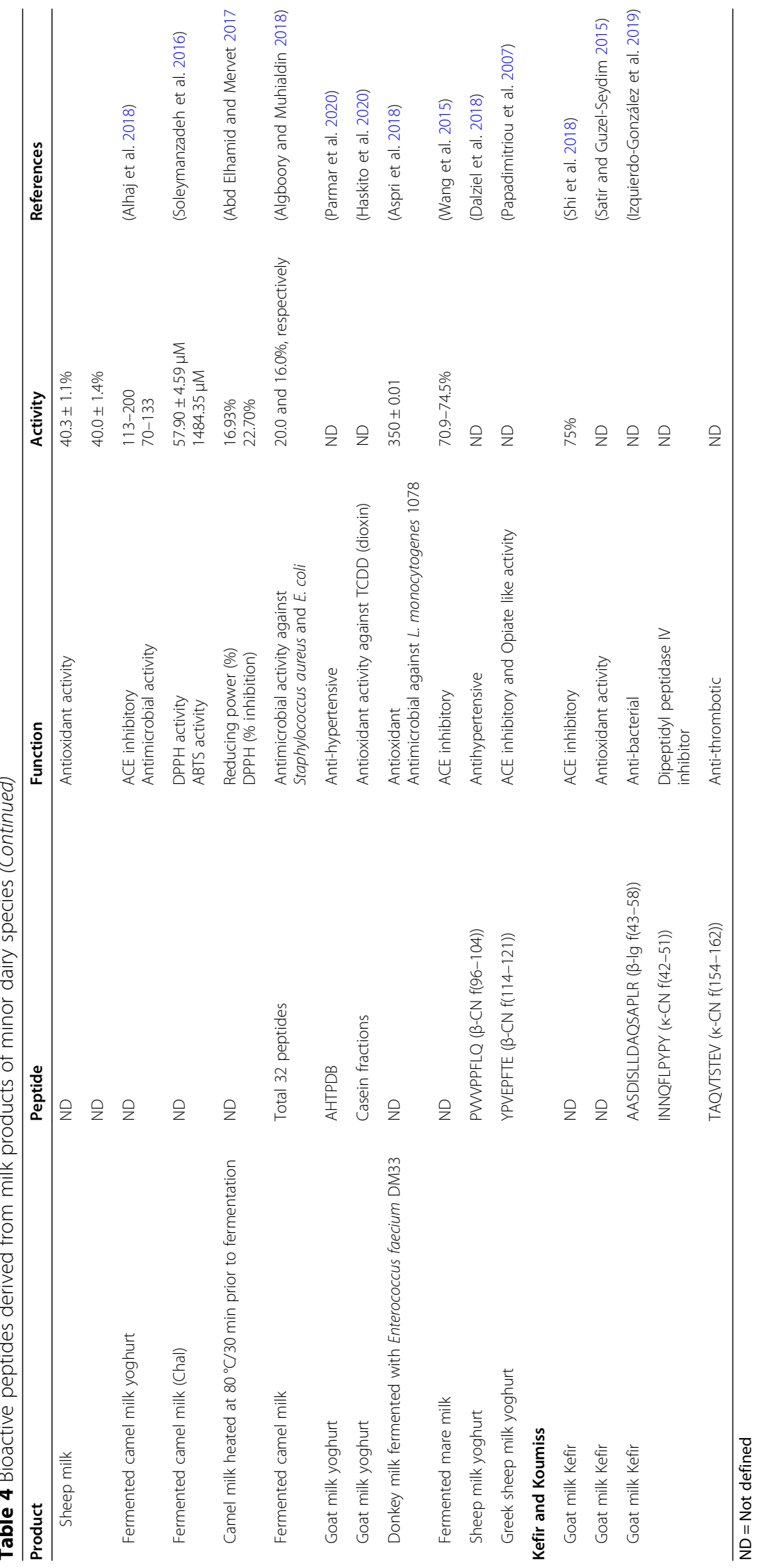


showed a similar peptide profile. ACE inhibitory activity increased during ripening to a certain level and decreased thereafter due to breakdown of responsible peptides to lower molecular weight fragments (Kocak et al. 2020).

A water-soluble peptide extract of Pecorino Romano cheese, made from sheep milk, was found to be potentially active against certain pathogenic bacteria such as Bacillus megaterium, E. coli, Yersinia enterocolitica, Lactobacillus innocua, Staphylococcus aureus, and Salmonella spp with minimum inhibitory doses ranging from 20 to $75 \mu \mathrm{g} / \mathrm{mL}$ (Rizzello et al. 2005).

Water soluble extracts of different market samples of feta, Roquefort, Pecorino Sardo-Cerrillano, and Pecorino cheese of sheep's milk possessed prominent antioxidant and ACE inhibitory activities. However, water soluble extracts of Roquefort-type displayed the best antihypertensive and antioxidative properties due to its complex peptide profile. Total nine peptides from $\beta$-casein fraction, five peptides from $\alpha_{\mathrm{s} 2}$-casein and three from $\alpha_{\mathrm{s} 1}$-casein were identified having antioxidant and ACE inhibitory peptides sequence homology identified in other cheeses. All the bioactive peptides had at least one proline amino acid residue which had been reported to contribute to ACE inhibitory and antioxidant activity (Meira et al. 2012). Sheep milk-based probiotic, Scamorza cheese, showed the potential of yielding bioactive peptides. Probiotic cultures (Bifidobacterium longum BL-46 and Bifidobacterium lactis BB-12) liberated higher amount of low molecular peptides during secondary proteolysis as compared to control cheese. The $\beta$-casein $f(210-220), \alpha_{s 1}$-casein $f(1-23), \kappa$-casein $f(78-90)$ and $\alpha_{\mathrm{s} 1}$-casein $\mathrm{f}(1-6)$ protein fragments were observed in Scamorza cheese (Albenzio et al. 2015). Atanasova et al. (2020) identified 31 and 22 bioactive peptides in sheep and goat milk-based white brined cheese of Bulgarian origin, respectively. Peptides were majorly obtained from hydrolysis of $\alpha_{s 1}$-casein, $\alpha_{s 2}$-casein and $\beta$-casein. The identified peptides were having ACE inhibitory, $\alpha_{\mathrm{s} 1}$-casokinins, caseinophosphopeptide and immune peptide activity (Table 4).

\section{Fermented milk (yoghurt)}

Bioactivities of fermented milk increase during initial storage period due to the active metabolism of the starter, followed by a decrease after a certain interval due to modification and degradation of the bioactive fractions (Sultan et al. 2017). Bioactive peptides derived from Lactobacillus acidophilus and Streptococcus thermophilus fermented camel milk showed ACE inhibitory and antimicrobial activities against Bacillus cereus, Salmonella Typhimurium, and Staphylococcus aureus. Bioactivities were time and strain-dependent wherein microbial inhibition activity was observed after $12 \mathrm{~h}$ of incubation till 15 days (Alhaj et al. 2018). Camel milk fermented by Leuconostoc lactis, isolated from traditional fermented camel milk (Chal),had antioxidant activity as revealed by significantly higher ABTS and DPPH activity (Soleymanzadeh et al. 2016). Antioxidant potential of camel milk increased after fermentation. Reducing power assay and percentage DPPH inhibition of yoghurt prepared from camel milk increased significantly $(p<0.01)$ on heating the camel milk at $80^{\circ} \mathrm{C}$ for 30 to $120 \mathrm{~min}$. On heating, protein unfolding and exposure of thiol groups acts as hydrogen donor while on severe heating, prooxidants get consumed during Maillard reaction, producing melanoidin with strong antioxidant activity. However, percentage inhibition decreased during cold storage of yoghurt. The bioactive peptides in yoghurt possessed antimicrobial potential against B. cereus, E. coli, and S. aureus (Elhamid \& Mervet, 2017). Camel milk fermented with Lactobacillus plantarum had 32 peptides belonging to lactophorin (6), $\alpha_{\mathrm{s} 2}$-casein (7), $\beta$-casein (9), $\alpha_{\mathrm{s} 1}$-casein (10) proteins and showed antimicrobial activity against Grampositive and Gram-negative bacteria including S. aureus, E. coli, Shigella dysenteriae, and Staphylococcus faecalis (Algboory and Muhialdin 2018).

Casein derived bioactive peptides from goat milk yoghurt reduced the renal and aorta malondialdehyde in deoxycorticosterone hypertensive rats (Padaga and Sujuti 2015). Goat (Beetal breed) and sheep (Kajli breed) yoghurt prepared using Streptococcus thermophilus and Lactobacillus bulgaricus showed anti-hypertensive and antioxidative potential. Peptide concentrations in goat and sheep yoghurt were $6.50 \mathrm{mg} / \mathrm{mL}$ and $5.13 \mathrm{mg} / \mathrm{mL}$, respectively, which increased during storage because of enzymatic proteolysis (Sultan et al. 2017). Three different 16 amino acids containing bioactive peptides in goat milk yoghurt from $\beta$-casein (LYQEPVLGPVRGPFPI, YQEPVLGPVRGPFPIL, and VQSWMHQPPQPLSPT) had antioxidant potential and protected rats from hypercholesterolemia (Mahdi et al. 2018). Goat milk fermented with five different Lactobacillus cultures showed different concentrations of antihypertensive and Xpropyl-dipeptidyl aminopeptidase activity due to modification in their proteolysis level (Parmar et al. 2020). Goat milk yoghurt prevented 2,3,7,8-tetrachlorodibenzo-p-diozin induced lung damage in male rats due to antioxidant activity of yoghurt casein (Haskito et al. 2020). Sheep milk based Greek yoghurt prepared with standard yoghurt culture and Lactobacillus paracasei subsp. paracasei DC412 possessed higher content of bioactive peptides in comparison to standard yoghurt culture-based product. Most of the peptides were derivative of casein and the fragment 114-121(YPVEPFTE) had ACE inhibitory and opioid like activity. However, the peptide content and anti-hypertensive properties of water-soluble extracts of Greek yoghurt increased during 
storage (Papadimitriou et al. 2007). Sheep milk yoghurt led to faster colonic transit in rats due to absence of $\beta$ casomorphin precursor as it promotes the feeling of satiety and calms down any colonic over-activity. Several identified bioactive peptides in sheep yoghurt included $\alpha_{\mathrm{s} 1}$-casein f25-32 (VVAPFPEVF) with ACE inhibitory properties, $\alpha_{\mathrm{s} 1}$-casein f180-193 (SDIPNPIGSENSGK) with anti-microbial activity, $\beta$-casein 1f66-175 (SQPK VLPVPQ) and $\beta$-casein 183-190 (RDMPIQAF) with antioxidant potential, $\beta$-casein 192-209 (LYQEPVLGPV RGPFPILV) with immunomodulation properties, and $\beta$ casein 193-207 (YQEPVLGPVRGPFPI) as an antimicrobial (Dalziel et al. 2018). Nguyen et al. (2020) reported that lower peptide release in sheep milk yoghurt during the early phase of gastric digestion was due to the dense network and higher gel firmness as compared to goat yoghurt. Dense gel network and cross-linked structures hinder the accessibility of enzyme to cleave protein, thereby slowing the peptide release. Both sheep and goat yoghurts contained a higher number of identified peptides as compared to their corresponding milk. The $\beta$ casein $\mathrm{f}(96-104)$ (PVVVPPFLQ) showed antihypertensive activity in goat and sheep milk yoghurt.

Donkey milk fermented with different Lactobacillus isolates exhibited antioxidative, antihypertensive, and antimicrobial properties. The coupled action of fermentation and in vitro simulated gastrointestinal digestion further enhanced the rich pool of bioactive peptides available in donkey milk. The highest numbers of peptides were derived from $\beta$-caseinand $\beta$-lactoglobulin, as their structures were more accessible to hydrolyzing enzymes (Aspri et al. 2018). Mare milk yoghurt possessed lower ACE inhibitory activity as compared to cow and soy milk due to absence of ACE-inhibitory tripeptides IPP and VPP in mare milk (Wang et al. 2015).

\section{Kefir and koumiss}

Kefir is a naturally carbonated fermented milk product produced using Kefir grains. Kefir grains consist of complex microflora which is responsible for the antihypertensive, antibacterial, and anti-inflammatory properties of Kefir (Biadała et al. 2020). Kefir grains from different regions of China revealed 3\% inoculum of $\mathrm{K} 1$ grains at $25^{\circ} \mathrm{C}$ for $22 \mathrm{~h}$ for the best production of goat milk-based kefir. K1 kefir grains also outperformed kefir grains from other locations in terms of ACE inhibitory and antioxidant activity (Shi et al. 2018). Goat milk of two different breeds, Hair and Saanen, showed significant increase in their antioxidant activity after being fermented with $2 \%$ natural Kefir grains (Satir and Guzel-Seydim 2015). Goat milk fermented with different strains of kefir grain namely Lactobacillus kefiranofaciens subsp. KefirgranumDSM 10,550, Lactobacillus kefiri PCM 2501, Lactobacillus parakefiri DSM 10551, Lactobacillus brevis
PCM 488, Lactobacillus delbrueckii subsp. lactis PCM 2611 showed antimicrobial activity against E. coli, Salmonella, Micrococcus luteus and Proteus mirabilis (Biadała et al. 2020). Different bioactivities of kefir were reported in literature, however, identification and characterization of such peptides is limited. IzquierdoGonzález et al. (2019) profiled the bioactive peptides in goat milk kefir after 12,24 and $36 \mathrm{~h}$ of fermentation using peptidomics approach. In total, 11 bioactive peptides (Table 4) were identified after different fermentation time; however, maximum concentration was obtained after $24 \mathrm{~h}$ which decreased thereafter. The number of peptides was almost similar to control after $12 \mathrm{~h}$ fermentation as kefir was not mature and the proteolysis was low.

\section{Future trends}

The ability to generate bioactive peptides by food commodities is considered an important parameter owing to their functional and nutritional properties. Proteins from cow milk have been studied extensively as sources of bioactive peptides. On the other hand, minor milk proteins and their related products have always been considered as the "dark" areas of research because of their low economic significance. However, in recent years this trend has been changing, as there is an increase in demand in finding alternative milk sources and milk products, particularly for their bioactive peptides. Various bioactive peptides, derived from different milk protein sources other than cow milk, have already shown diverse biological activities such as ACE-inhibitory, metalbinding, antioxidant, antimicrobial activities among many more, which have revealed unique peptides. However, there still exists a huge gap in knowledge in terms of stability, bioavailability, and efficiency of these peptides, particularly in in vivo experiments and clinical trials, which paves a huge path for understanding the role of these peptides in human health. A better understanding of these minor milk protein-derived peptides would also aid the commercialization of the peptides for dietary uses. This could be done by the following approaches:

- The use of recombinant enzymes and specific microbial fermentations, such as use of special coagulating enzymes during cheese fermentations, could be a useful technique to give rise to novel peptides from different milk and their associated products.

- Understanding the structure-function relationship of the peptides for a better insight into the biochemical functions and their dietary implications using powerful tools, such as cell culture, -omics, imaging, and gut microbiome research. 
- Examining the toxicity, allergenicity, and stability of the peptides during gastrointestinal digestion of the formulations after incorporating the bioactive peptides into them.

Thus, minor milk protein-derived bioactive peptides hold an enormous potential in the development of nutraceuticals and functional foods which could be used as a health ingredient. Also, characterization of bioactive peptides derived from minor milk species would help in their popularity and recognition across the globe.

\section{Conclusion}

The research on milk and milk products from minor dairy species have been less promoted due to lesser animal population with corresponding limited significance in the economy. The availability of minor dairy animal's milk and milk products is also limited to local and regional areas. However, the growing interest of consumers towards authentic traditional foods and substitute of bovine milk with multifunctional properties, has lightened them globally. Bioactive peptides liberated from bovine milk proteins have been reported to possess various activities, such as, antihypertensive, antioxidative, antimicrobial, mineral binding, and immunomodulatory, etc. which represent its health and nutritional importance. However, more sophisticated and long-term animal and human studies are needed to validate these health benefits. Although rational information on bioactive peptides from goat and sheep milk proteins is available now, limited research has been done on bioactive peptides from other minor dairy animal's milk and milk products. Identification, characterization and application of bioactive peptides requires more attention of scientific community which would be helpful in commercial application of milk protein derived bioactive peptides from milk and milk products of minor dairy animals to improve human health.

\section{Acknowledgements}

The graphical abstract has been created in Biorender.com and exported under a paid subscription.

\section{Authors' contributions}

SG, HS and PSR conceived and designed the paper; SG, HS, and GKD collected and analyzed literatures and wrote the paper; PSR, HS, SG edited the table and figure, PSR reviewed and edited the manuscript. The authors read and approved the final manuscript.

\section{Funding}

The authors declare that no funding was provided for the present work.

\section{Availability of data and materials}

Data and materials used include all the original reviewed articles which are available.

\section{Competing interests}

The authors declare no competing interests.

\section{Author details}

${ }^{1}$ Department of Food Science and Technology, University of Nebraska-Lincoln, Lincoln, NE 68588-6205, USA. ${ }^{2}$ Food Technology Laboratory, Dairy Technology Division, National Dairy Research Institute (ICAR-NDRI), Karnal, Haryana 132001, India. ${ }^{3}$ Dairy Chemistry and Bacteriology Section, Southern Regional Station-National Dairy Research Institute, Bengaluru 560030, India.

Received: 30 September 2020 Accepted: 29 November 2020

Published online: 11 January 2021

\section{References}

Abd Elhamid, A. M., \& Mervet, M. E. (2017). Effect of heat treatment and fermentation on bioactive behavior in yoghurt made from camel Milk. American Journal of Food Science and Technology, 5(3), 109-116.

Abu-qatouseh, L. (2019). Antimicrobial and anti-inflammatory activity of camel milk derived immune proteins and peptides against Propionibacterium acnes. International Journal of Biology, Pharmacy and Allied Sciences. https:// doi.org/10.31032/ijbpas/2019/8.1.4623.

Ahmed, A. S., El-Bassiony, T., Elmalt, L. M., \& Ibrahim, H. R. (2015). Identification of potent antioxidant bioactive peptides from goat milk proteins. Food Research International, 74, 80-88 https://doi.org/10.1016/j.foodres.2015.04.032.

Al Haj, O. A., \& Al Kanhal, H. A. (2010). Compositional, technological and nutritional aspects of dromedary camel milk. International Dairy Journal, 20(12), 811-821 Elsevier. https://doi.org/10.1016/j.idairyj.2010.04.003.

Albenzio, M., Santillo, A., Marino, R., Della Malva, A., Caroprese, M., \& Sevi, A. (2015). Identification of peptides in functional Scamorza ovine milk cheese. Journal of Dairy Science, 98(12), 8428-8432 https://doi.org/10.3168/jds.20159844.

Algboory, H. L., \& Muhialdin, B. J. (2018). Identification of low molecular weight antimicrobial peptides from Iraqi camel milk fermented with lactobacillus plantarum. PharmaNutrition, 6(2), 69-73 https://doi.org/10.1016/j.phanu.2018. 02.002.

Alhaj, O. A. (2017). Identificación de los péptidos inhibidores de ACE potenciales en leche fermentada de dromedario. CyTA Journal of Food, 15(2), 191-195 https://doi.org/10.1080/19476337.2016.1236353.

Alhaj, O. A., Metwalli, A. A., Ismail, E. A., Ali, H. S., Al-Khalifa, A. S., \& Kanekanian, A. D. (2018). Angiotensin converting enzyme-inhibitory activity and antimicrobial effect of fermented camel milk ( Camelus dromedarius ). International Journal of Dairy Technology, 71(1), 27-35 https://doi.org/10.1111/ 1471-0307.12383.

Alichanidis, E., Moatsou, G., \& Polychroniadou, A. (2016). Composition and properties of non-cow milk and products. In Non-bovine milk and milk products. Elsevier Inc https://doi.org/10.1016/B978-0-12-803361-6.00005-3.

Aslam, M. Z., Shoukat, S., Hongfei, Z., \& Bolin, Z. (2018). Proteomic analysis of ACE inhibitory peptides extracted from fermented goat milk. In Peptidomic analysis of ACE inhibitory peptides extracted from fermented goat milk, ( $p$. 336107) https://doi.org/10.1101/336107.

Aspri, M., Leni, G., Galaverna, G., \& Papademas, P. (2018). Bioactive properties of fermented donkey milk, before and after in vitro simulated gastrointestinal digestion. Food Chemistry, 268, 476-484 https://doi.org/10.1016/j.foodchem. 2018.06.119.

Atanasova, J., Dalgalarrondo, M., Iliev, I., Moncheva, P., Todorov, S. D., \& Ivanova, I. V. (2020). Formation of free amino acids and bioactive peptides during the ripening of Bulgarian white brined cheeses. Probiotics and Antimicrobial Proteins. https://doi.org/10.1007/s12602-020-09669-0.

Augustin, M. A., \& Udabage, P. (2007). Influence of processing on functionality of milk and dairy proteins. Advances in Food and Nutrition Research, 53, 1-38 https://doi.org/10.1016/S1043-4526(07)53001-9.

Bao, C., Chen, H., Chen, L., Cao, J., \& Meng, J. (2016). Comparison of ACE inhibitory activity in skimmed goat and cow milk hydrolyzed by Alcalase, flavourzyme, neutral protease and proteinase K. Acta Universitatis Cibiniensis. Series E: Food Technology, 20(1), 77-84 https://doi.org/10.1515/aucft-2016-0006.

BEG, O. U., von BAHR-LINDSTRÖM, H., ZAIDI, Z. H., \& JÖRNVALL, H. (1985). The primary structure of a-lactalbumin from camel milk. European Journal of Biochemistry., 147(2), 233-239. https://doi.org/10.1111/j.1432-1033.1985. tb08741.x.

Biadała, A., Szablewski, T., Lasik-Kurdyś, M., \& Cegielska-Radziejewska, R. (2020). Antimicrobial activity of goat's milk fermented by single strain of kefir grain microflora. European Food Research and Technology, 246(6), 1231-1239 https://doi.org/10.1007/s00217-020-03483-2. 
Bidasolo, I. B., Ramos, M., \& Gomez-Ruiz, J. A. (2012). In vitro simulated gastrointestinal digestion of donkeys' milk. Peptide characterization by high performance liquid chromatography-tandem mass spectrometry. International Dairy Journal, 24(2), 146-152 https://doi.org/10.1016/j.idairyj.2011.04.014.

Chen, L., Zhang, Q., Ji, Z., Shu, G., \& Chen, H. (2018). Production and fermentation characteristics of angiotensin-I-converting enzyme inhibitory peptides of goat milk fermented by a novel wild lactobacillus plantarum 69. LWT - Food Science and Technology, 91, 532-540 https://doi.org/10.1016/j.lwt.2018.02.002.

Chen, Y., Wang, Z., Chen, X., Liu, Y., Zhang, H., \& Sun, T. (2010). Identification of angiotensin I-converting enzyme inhibitory peptides from koumiss, a traditional fermented mare's milk. Journal of Dairy Science, 93(3), 884-892 https://doi.org/10.3168/jds.2009-2672.

Corrêa, A. P. F., Daroit, D. J., Coelho, J., Meira, S. M., Lopes, F. C., Segalin, J., .. Brandelli, A. (2011). Antioxidant, antihypertensive and antimicrobial properties of ovine milk caseinate hydrolyzed with a microbial protease. Journal of the Science of Food and Agriculture, 91(12), 2247-2254 https://doi.org/10.1002/jsfa. 4446.

Dalziel, J. E., Smolenski, G. A., McKenzie, C. M., Haines, S. R., \& Day, L. (2018). Differential effects of sheep and cow skim milk before and after fermentation on gastrointestinal transit of solids in a rat model. Journal of Functional Foods, 47(August 2017), 116-126 https://doi.org/10.1016/j.jf.2018.05.039.

De Gobba, C., Espejo-Carpio, F. J., Skibsted, L. H., \& Otte, J. (2014). Antioxidant peptides from goat milk protein fractions hydrolysed by two commercial proteases. International Dairy Journal, 39(1), 28-40 https://doi.org/10.1016/j. idairyj.2014.03.015.

Eigel, W. N., Butler, J. E., Ernstrom, C. A., Farrell, H. M., Harwalkar, V. R., Jenness, R., \& Whitney, R. M. L. (1984). Nomenclature of proteins of Cow's milk: Fifth revision. Journal of Dairy Science, 67(8), 1599-1631 https://doi.org/10.3168/jds. S0022-0302(84)81485-X.

Elzahar, K., Sitohy, M., \& Haertlé, T. (2004). Antimicrobial activity of ovine whey protein and their peptic hydrolysates. Milchwissenschaft, 59(11/12), 653-656 https://www.researchgate.net/publication/279541319. Accessed 5 Dec 2020.

Esmaeilpour, M., Ehsani, M. R., Aminlari, M., Shekarforoush, S., \& Hoseini, E. (2016). Antimicrobial activity of peptides derived from enzymatic hydrolysis of goat milk caseins. Comparative Clinical Pathology, 25(3), 599-605 https://doi.org/10. 1007/s00580-016-2237-x.

Espejo-Carpio, F. J., Pérez-Gálvez, R., Del Carmen Almécija, M., Guadix, A., \& Guadix, E. M. (2014). Production of goat milk protein hydrolysate enriched in ACE-inhibitory peptides by ultrafiltration. Journal of Dairy Research, 81(4), 385-393 https://doi.org/10.1017/S0022029914000284.

FAO (2013). MILK human nutrition dairy products. www.fao.org/.

Farrell, H. M., Jimenez-Flores, R., Bleck, G. T., Brown, E. M., Butler, J. E., Creamer, L. K., .. Swaisgood, H. E. (2004). Nomenclature of the proteins of cows' milk sixth revision. Journal of Dairy Science, 87(6), 1641-1674 https://doi.org/10. 3168/jds.S0022-0302(04)73319-6.

Food and Agriculture Organization of the United Nations. (n.d.).

Geerlings, A., Villar, I. C., Zarco, F. H., Sánchez, M., Vera, R., Gomez, A. Z., ... Duarte, J. (2006). Identification and characterization of novel angiotensin-converting enzyme inhibitors obtained from goat milk. Journal of Dairy Science, 89(9), 3326-3335 https://doi.org/10.3168/jds.S0022-0302(06)72369-4.

Gerosa, S., \& Skoet, J. (2012). Milk availability trends in production and demand and medium-term outlook. www.fao.org/economic/esa.

Giacometti, J., \& Buretić-Tomljanović, A. (2017). Peptidomics as a tool for characterizing bioactive milk peptides. Food Chemistry, 230, 91-98 https://doi. org/10.1016/j.foodchem.2017.03.016.

Girardet, J. M., Saulnier, F., Gaillard, J. L., Ramet, J. P., \& Humbert, G. (2000). Camel (camelus dromedarius) milk PP3: Evidence for an insertion in the aminoterminal sequence of the camel milk whey protein. Biochemistry and Cell Biology., 78(1), 19-26. https://doi.org/10.1139/099-067.

Gobbetti, M., Minervini, F., \& Rizzello, C. (2007). Bioactive peptides in dairy products. In Handbook of food products manufacturing-health, meat, milk, poultry, seafood, and vegetables, (pp. 489-517). Wiley https://ci.nii.ac.jp/naid/1 0027222780

Gómez-Ruiz, J. Á., López-Expósito, I., Pihlanto, A., Ramos, M., \& Recio, I. (2008). Antioxidant activity of ovine casein hydrolysates: Identification of active peptides by HPLC-MS/MS. European Food Research and Technology. https:// doi.org/10.1007/s00217-008-0820-3.

Gómez-Ruiz, J. Á., Ramos, M., \& Recio, I. (2007). Identification of novel angiotensin-converting enzyme-inhibitory peptides from ovine milk proteins by CE-MS and chromatographic techniques. Electrophoresis., 28(22), 42024211. https://doi.org/10.1002/elps.200700324.
Gómez-Ruiz, J. Á., Taborda, G., Amigo, L., Recio, l., \& Ramos, M. (2006). Identification of ACE-inhibitory peptides in different Spanish cheeses by tandem mass spectrometry. European Food Research and Technology, 223(5), 595-601 https://doi.org/10.1007/s00217-005-0238-0.

Gong, H., Gao, J., Wang, Y., Luo, Q. W., Guo, K. R., Ren, F. Z., \& Mao, X. Y. (2020). Identification of novel peptides from goat milk casein that ameliorate highglucose-induced insulin resistance in HepG2 cells. Journal of Dairy Science, 103(6), 4907-4918 https://doi.org/10.3168/jds.2019-17513.

Guo, H. Y., Pang, K., Zhang, X. Y., Zhao, L., Chen, S. W., Dong, M. L., \& Ren, F. Z. (2007). Composition, physiochemical properties, nitrogen fraction distribution, and amino acid profile of donkey milk. Journal of Dairy Science, 90(4), 1635-1643 https://doi.org/10.3168/jds.2006-600.

Haskito, A. E. P., Mahdi, C., Padaga, M. C., \& Roosdiana, A. (2020). The effect of goat milk yoghurt casein antioxidant activity on histopathology of lung in male Rattus norvegicus exposed by 2,3,7,8-tetrachlorodibenzo-p-dioxin (TCDD). Journal of Physics: Conference Series, 1430(1) https://doi.org/10.1088/ 1742-6596/1430/1/012010.

Hernández-Galán, L., Cardador-Martínez, A., López-del-Castillo, M., Picque, D., Spinnler, H. E., \& Martín del Campo, S. T. (2017). Actividad antioxidante e inhibitoria de la enzima convertidora de angiotensina en queso fresco de Cabra preparado sin cultivos iniciadores: Estudio preliminar. CyTA Journal of Food, 15(1), 49-57 https://doi.org/10.1080/19476337.2016.1202325.

Homayouni-Tabrizi, M., Asoodeh, A., \& Soltani, M. (2017). Cytotoxic and antioxidant capacity of camel milk peptides: Effects of isolated peptide on superoxide dismutase and catalase gene expression. Journal of Food and Drug Analysis, 25(3), 567-575 https://doi.org/10.1016/j.jfda.2016.10.014.

Ibrahim, H. R., Ahmed, A. S., \& Miyata, T. (2017). Novel angiotensin-converting enzyme inhibitory peptides from caseins and whey proteins of goat milk. Journal of Advanced Research, 8(1), 63-71 https://doi.org/10.1016/j.jare.2016. 12.002.

Ibrahim, H. R., Isono, H., \& Miyata, T. (2018). Potential antioxidant bioactive peptides from camel milk proteins. Animal Nutrition, 4(3), 273-280 https://doi. org/10.1016/j.aninu.2018.05.004.

Izquierdo-González, J. J., Amil-Ruiz, F., Zazzu, S., Sánchez-Lucas, R., FuentesAlmagro, C. A., \& Rodríguez-Ortega, M. J. (2019). Proteomic analysis of goat milk kefir: Profiling the fermentation-time dependent protein digestion and identification of potential peptides with biological activity. Food Chemistry, 295(May), 456-465 https://doi.org/10.1016/j.foodchem.2019.05.178.

Jiang, J., Chen, S., Ren, F., Luo, Z., \& Zeng, S. S. (2007). Yak milk casein as a functional ingredient: Preparation and identification of angiotensin--converting enzyme inhibitory peptides. Journal of Dairy Research, 74(1), 18-25 https://doi.org/10.1017/S0022029906002056.

Jrad, Z., El Hatmi, H., Adt, I., Girardet, J. M., Cakir-Kiefer, C., Jardin, J., ... Oulahal, N. (2014). Effect of digestive enzymes on antimicrobial, radical scavenging and angiotensin l-converting enzyme inhibitory activities of camel colostrum and milk proteins. Dairy Science and Technology, 94(3), 205-224 https://doi.org/10. 1007/s13594-013-0154-1.

Kappeler, S. R., Farah, Z., \& Puhan, Z. (2003). 5'-flanking regions of camel milk genes are highly similar to homologue regions of other species and can be divided into two distinct groups. Journal of Dairy Science, 86(2), 498-508 https://doi.org/10.3168/jds.S0022-0302(03)73628-5.

Kocak, A., Sanli, T., Anli, E. A., \& Hayaloglu, A. A. (2020). Role of using adjunct cultures in release of bioactive peptides in white-brined goat-milk cheese. Lwt, 123(February), 109127 https://doi.org/10.1016/j.lwt.2020.109127.

Korhonen, H., \& Pihlanto-Leppala, A. (2004). Milk-derived bioactive peptides: Formation and prospects for health promotion. In C. Shortt, \& J. O'Brien (Eds. ). Handbook of functional dairy products, (pp. 109-124). Boca Raton: CRC Press https://scholar.google.com/scholar_lookup?title=Handbook+of+ Functional+Dairy+Products\&publication_year $=2004 \&$.

Kumar, D., Chatli, M. K., Singh, R., Mehta, N., \& Kumar, P. (2016a). Antioxidant and antimicrobial activity of camel milk casein hydrolysates and its fractions. Small Ruminant Research, 139, 20-25 https://doi.org/10.1016/j.smallrumres. 2016.05.002.

Kumar, D., Chatli, M. K., Singh, R., Mehta, N., \& Kumar, P. (2016b). Enzymatic hydrolysis of camel milk casein and its antioxidant properties. Dairy Science and Technology, 96(3), 391-404 https://doi.org/10.1007/s13594015-0275-9.

Kusumaningtyas, E., Widiastuti, R., Kusumaningrum, H. D., \& Suhartono, M. T. (2018). Bioactivities and analysis of peptides from Sumbawa horse milk generated by bacillus thuringiensis protease. Jurnal IImu Ternak Dan Veteriner, 21(4), 244 https://doi.org/10.14334/jitv.v21i4.1627. 
Lestari, P., \& Suyata (2019). Antibacterial activity of hydrolysate protein from Etawa goat milk hydrolysed by crude extract bromelain. IOP Conference Series: Materials Science and Engineering, 509(1) https://doi.org/10.1088/1757899X/509/1/012111.

Li, Z., Jiang, A., Yue, T., Wang, J., Wang, Y., \& Su, J. (2013). Purification and identification of five novel antioxidant peptides from goat milk casein hydrolysates. Journal of Dairy Science. https://doi.org/10.3168/jds.2012-6511.

Lin, K., Zhang, L. W., Han, X., Xin, L., Meng, Z. X., Gong, P. M., \& Cheng, D. Y. (2018). Yak milk casein as potential precursor of angiotensin I-converting enzyme inhibitory peptides based on in silico proteolysis. Food Chemistry, 254, 340-347 https://doi.org/10.1016/j.foodchem.2018.02.051.

López-Expósito, I., Gómez-Ruiz, J. Á., Amigo, L., \& Recio, I. (2006). Identification of antibacterial peptides from ovine as2-casein. International Dairy Journal., 16(9), 1072-1080. https://doi.org/10.1016/j.idairyj.2005.10.006.

Lozovich, S. (1995). Medical uses of whole and fermented mare milk in Russia. Medicine, 30(1), 18-21

Luz, C., Izzo, L., Ritieni, A., Mañes, J., \& Meca, G. (2020). Antifungal and antimycotoxigenic activity of hydrolyzed goat whey on Penicillium spp: An application as biopreservation agent in pita bread. Lwt, 118(June 2019), 108717 https://doi.org/10.1016/j.lwt.2019.108717.

Mahdi, C., Untari, H., \& Padaga, M. C. (2018). Identification and characterization of bioactive peptides of fermented goat milk as a source of antioxidant as a therapeutic natural product. In IOP conference series: materials science and engineering (Vol. 299, No. 1, p. 012014). IOP Publishing.

Malacarne, M., Martuzzi, F., Summer, A., \& Mariani, P. (2002). Protein and fat composition of mare's milk: Some nutritional remarks with reference to human and cow's milk. International Dairy Journal, 12(11), 869-877 https:// doi.org/10.1016/S0958-6946(02)00120-6.

Manso, M. A., \& López-Fandiño, R. (2003). Angiotensin I converting enzyme Inhibitory activity of bovine, ovine, and caprine k-casein macropeptides and their tryptic hydrolysates. Journal of Food Protection., 66(9), 1686-1692. https://doi.org/10.4315/0362-028X-66.9.1686.

Mao, X. Y., Cheng, X., Wang, X., \& Wu, S. J. (2011). Free-radical-scavenging and anti-inflammatory effect of yak milk casein before and after enzymatic hydrolysis. Food Chemistry, 126(2), 484-490 https://doi.org/10.1016/j. foodchem.2010.11.025.

Mao, X. Y., Ni, J. R., Sun, W. L., Hao, P. P., \& Fan, L. (2007b). Value-added utilization of yak milk casein for the production of angiotensin-1-converting enzyme inhibitory peptides. Food Chemistry, 103(4), 1282-1287 https://doi.org/10. 1016/j.foodchem.2006.10.041.

Mao, X. Y., Ren, F. Z., Li, Y. H., \& Nan, Q. X. (2005). Growth-inhibiting activity of casein and its hydrolysate to tumor cells. Milchwissenschaft, 61(2), 127-130.

Mao, X. Y., Yang, H. Y., Song, J. P., Li, Y. H., \& Ren, F. Z. (2007a). Effect of yak milk casein hydrolysate on Th1/Th2 cytokines production by murine spleen lymphocytes in vitro. Journal of Agricultural and Food Chemistry, 55(3), 638642 https://doi.org/10.1021/jf062452m.

Marletta, D., Criscione, A., Bordonaro, S., Guastella, A. M., \& Urso, G. D. (2007). Casein polymorphism in goat's milk. Lait, 87, 491-504 https://doi.org/10. 1051/lait:2007034.

Martini, M., Altomonte, I., Licitra, R., \& Salari, F. (2018). Nutritional and Nutraceutical quality of donkey milk. Journal of Equine Veterinary Science, 65, 33-37 https://doi.org/10.1016/j.jevs.2017.10.020

Martini, M., Altomonte, I., Salari, F., \& Caroli, A. M. (2014). Short communication: Monitoring nutritional quality of amiata donkey milk: Effects of lactation and productive season. Journal of Dairy Science, 97(11), 6819-6822 https://doi.org/ 10.3168/jds.2014-8544.

McGrath, B. A., Fox, P. F., McSweeney, P. L. H., \& Kelly, A. L. (2016). Composition and properties of bovine colostrum: A review. Dairy Science and Technology, 96(2), 133-158. Springer-Verlag France. https://doi.org/10.1007/s13594-0150258-x.

Medhammar, E., Wijesinha-Bettoni, R., Stadlmayr, B., Nilsson, E., Charrondiere, U. R., \& Burlingame, B. (2012). Composition of milk from minor dairy animals and buffalo breeds: A biodiversity perspective. Journal of the Science of Food and Agriculture, 92(3), 445-474 https://doi.org/10.1002/jsfa.4690.

Meira, S. M. M., Daroit, D. J., Helfer, V. E., Corrêa, A. P. F., Segalin, J., Carro, S., \& Brandelli, A. (2012). Bioactive peptides in water-soluble extracts of ovine cheeses from southern Brazil and Uruguay. Food Research International, 48(1), 322-329 https://doi.org/10.1016/j.foodres.2012.05.009.

Miao, W., He, R., Feng, L., Ma, K., Zhang, C., Zhou, J., ... Xu, Q. (2020). Study on processing stability and fermentation characteristics of donkey milk. Lwt, 124(February) https://doi.org/10.1016/j.lwt.2020.109151.
Michaelidou, A. M. (2008). Factors influencing nutritional and health profile of milk and milk products. Small Ruminant Research, 79(1), 42-50 https://doi. org/10.1016/j.smallrumres.2008.07.007.

Minervini, F., Algaron, F., Rizzello, C. G., Fox, P. F., Monnet, V., \& Gobbetti, M. (2003). Angiotensin I-converting-enzyme-inhibitory and antibacterial peptides from lactobacillus helveticus PR4 proteinase-hydrolyzed caseins of milk from six species. Applied and Environmental Microbiology, 69(9), 5297-5305 https:// doi.org/10.1128/AEM.69.9.5297-5305.2003.

Miranda, G., Mahé, M.-F., Leroux, C., \& Martin, P. (2004). Proteomic tools to characterize the protein fraction ofEquidae milk. PROTEOMICS, 4(8), 24962509 https://doi.org/10.1002/pmic.200300765.

Moatsou, G., Hatzinaki, A., Samolada, M., \& Anifantakis, E. (2005). Major whey proteins in ovine and caprine acid wheys from indigenous greek breeds. International Dairy Journal, 15(2), 123-131 https://doi.org/10.1016/j.idairyj. 2004.06.005.

Moatsou, G., Samolada, M., Katsabeki, A., \& Anifantakis, E. (2004). Casein fraction of ovine milk from indigenous Greek breeds. Lait, 84(3), 285-296 https://doi.org/ 10.1051/lait:2004006.

Moatsou, G., Vamvakaki, A. N., Mollé, D., Anifantakis, E., \& Léonil, J. (2006). Protein composition and polymorphism in the milk of Skopelos goats. Lait, 86(5), 345-357 https://doi.org/10.1051/lait:2006017.

Moslehishad, M., Ehsani, M. R., Salami, M., Mirdamadi, S., Ezzatpanah, H., Naslaji, A. N., \& Moosavi-Movahedi, A. A. (2013). The comparative assessment of ACEinhibitory and antioxidant activities of peptide fractions obtained from fermented camel and bovine milk by lactobacillus rhamnosus PTCC 1637. International Dairy Journal, 29(2), 82-87 https://doi.org/10.1016/j.idairyj.2012 10.015.

Mudgil, P., Baby, B., Ngoh, Y., Vijayan, R., Gan, C., \& Maqsood, S. (2019). Indentification and molecular docking study of novel cholesterol esterase inhibitory peptides from camel milk proteins. Journal of Dairy Science., 102 https://doi.org/10.3168/jds.2019-16520.

Mudgil, P., Kamal, H., Yuen, G. C., \& Maqsood, S. (2018). Characterization and identification of novel antidiabetic and anti-obesity peptides from camel milk protein hydrolysates. Food Chemistry, 259, 46-54 https://doi.org/10.1016/j. foodchem.2018.03.082.

Nguyen, H. T. H., Gathercole, J. L., Day, L., \& Dalziel, J. E. (2020). Differences in peptide generation following in vitro gastrointestinal digestion of yogurt and milk from cow, sheep and goat. Food Chemistry, 317(February), 126419 https://doi.org/10.1016/j.foodchem.2020.126419.

Nongonierma, A. B., Paolella, S., Mudgil, P., Maqsood, S., \& FitzGerald, R. J. (2017). Dipeptidyl peptidase IV (DPP-IV) inhibitory properties of camel milk protein hydrolysates generated with trypsin. Journal of Functional Foods., 34, 49-58. https://doi.org/10.1016/j.jf.2017.04.016.

Nongonierma, A. B., Paolella, S., Mudgil, P., Maqsood, S., \& FitzGerald, R. J. (2018). Identification of novel dipeptidyl peptidase IV (DPP-IV) inhibitory peptides in camel milk protein hydrolysates. Food Chemistry https://doi.org/10.1016/j. foodchem.2017.10.033.

Nuñez, M., \& de Renobales, M. (2016). IDF international symposium on sheep, goat and other non-cow milk. International Dairy Journal, 58(58), 1 https://doi. org/10.1016/j.idairyj.2016.02.044.

Ochirkhuyag, B., Chobert, J. M., Dalgalarrondo, M., Choiset, Y., \& Haertlé, T. (1997). Characterization of caseins from Mongolian yak, khainak, and bactrian camel. Lait, 77(5), 601-613 https://doi.org/10.1051/lait:1997543.

Osman, A., Goda, H. A., Abdel-Hamid, M., Badran, S. M., \& Otte, J. (2016). Antibacterial peptides generated by Alcalase hydrolysis of goat whey. LWT Food Science and Technology, 65, 480-486 https://doi.org/10.1016/j.lwt.2015. 08.043.

Öztürk, H. I., \& Akin, N. (2018). Comparison of some functionalities of water soluble peptides derived from Turkish cow and goat milk tulum cheeses during ripening. Food Science and Technology, 38(4), 674-682 https://doi.org/ 10.1590/1678-457x.11917.

Padaga, C., \& Sujuti, H. (2015). Blood pressure lowering effect and Antioxidative activity of casein derived from goat milk yogurt in DOCA-salt hypertensive rats. Undefined.

Papadimitriou, C. G., Vafopoulou-Mastrojiannaki, A., Silva, S. V., Gomes, A. M., Malcata, F. X., \& Alichanidis, E. (2007). Identification of peptides in traditional and probiotic sheep milk yoghurt with angiotensin I-converting enzyme (ACE)-inhibitory activity. Food Chemistry, 105(2), 647-656 https://doi.org/10. 1016/j.foodchem.2007.04.028.

Park, Y. W. (2009a). Bioactive components of goat milk. In Bioactive components in milk and dairy products, (pp. 43-82). Ames and Oxford: Wiley-Blackwell 
Publishers https://books.google.co.in/books?hl=en\&lr=\&id=VFpG2 doYN7IC\&oi=fnd\&pg=PR5\&dq=Park+Y.+W.+Overview+of+bioactive+ components+in+milk+and+dairy+products\&ots=YUT8ef-vPs\&sig= 8FdLdNToStmLnNIAZpFk8FHkjnc\&redir_esc=y\#v=onepage\&q=Park.Y.W. Overview.of.bioactive.comp.

Park, Y. W. (2009b). Overview of bioactive components in milk and dairy products. In Y. W. Park (Ed.), Bioactive components in milk and dairy products, (pp. 3-14). Wiley-Blackwell https://doi.org/10.1002/9780813821504.

Park, Y. W., \& Haenlein, G. F. W. (2006). Overview of milk of non-bovine mammals. In Handbook of milk of non-bovine mammals, (pp. 3-9). Ames: Blackwell Publishing Professional. https://doi.org/10.1002/9780470999738.ch1.

Park, Y. W., \& Nam, M. S. (2015). Bioactive peptides in milk and dairy products: A review. Korean Journal for Food Science of Animal Resources, 35(6), 831-840 https://doi.org/10.5851/kosfa.2015.35.6.831.

Parmar, H., Hati, S., Panchal, G., \& Sakure, A. A. (2020). Purification and production of novel angiotensin I-converting enzyme (ACE) inhibitory bioactive peptides derived from fermented goat milk. International Journal of Peptide Research and Therapeutics, 26(2), 997-1011 https://doi.org/10.1007/s10989-019-09902-7.

Pei, J., Jiang, H., Li, X., Jin, W., \& Tao, Y. (2017). Antimicrobial peptides sourced from post-butter processing waste yak milk protein hydrolysates. $A M B$ Express, 7(1), 217 https://doi.org/10.1186/s13568-017-0497-8.

Piovesana, S., Capriotti, A. L., Cavaliere, C., La Barbera, G., Samperi, R., Zenezini Chiozzi, R., \& Laganà, A. (2015). Peptidome characterization and bioactivity analysis of donkey milk. Journal of Proteomics, 119(34), 21-29 https://doi.org/ 10.1016/j.jprot.2015.01.020.

Potočnik, K., Gantner, V., Kuterovac, K., \& Cividini, A. (2011). Mare's milk: Composition and protein fraction in comparison with different milk species. Mljekarstvo, 61(2), 107-113.

Qian, Z. Y., Jollès, P., Migliore-Samour, D., Schoentgen, F., \& Fiat, A. M. (1995). Sheep k-casein peptides inhibit platelet aggregation. BBA - General Subjects, 1244(2-3), 411-417 https://doi.org/10.1016/0304-4165(95)00047-F.

Rahimi, M., Ghaffar, S. M., Salami, M., Mousavy, S. J., Niasari-Naslaji, A., Jahanbani, R., ... Moosavi-Movahedi, A. A. (2016). ACE- inhibitory and radical scavenging activities of bioactive peptides obtained from camel milk casein hydrolysis with proteinase $\mathrm{K}$. Dairy Science and Technology. https://doi.org/10.1007/s13594-016-0283-4.

Recio, I., de la Fuente, M. A., Jurez, M., \& Ramos, M. (2009). Bioactive components in sheep milk. In Bioactive components in milk and dairy products, (pp. 83104). Wiley-Blackwell https://doi.org/10.1002/9780813821504.ch4.

Regester, G. O., Smithers, G. W., Mitchell, I. R., McIntosh, G. H., \& Dionysius, D. A. (1997). Bioactive factors in milk: Natural and induced. In R. Welch, D. Burns, S. Davis, A. Popay, \& C. Prosser (Eds.), Milk composition, production and biotechnology, (pp. 119-132) http://www.sidalc.net/cgi-bin/wxis.exe/?lsisScript= UAA.xis\&method $=$ post\&formato $=2 \&$ cantidad $=1 \&$ expresion $=m f n=002897$.

Ricci, I., Artacho, R., \& Olalla, M. (2010). Milk protein peptides with angiotensin Iconverting enzyme inhibitory (ACEI) activity. Critical Reviews in Food Science and Nutrition, 50(5), 390-402 https://doi.org/10.1080/10408390802304198.

Rizzello, C. G., Losito, I., Gobbetti, M., Carbonara, T., De Bari, M. D., \& Zambonin, P. G. (2005). Antibacterial activities of peptides from the water-soluble extracts of Italian cheese varieties. Journal of Dairy Science., 88(7), 2348-2360. https:// doi.org/10.3168/jds.S0022-0302(05)72913-1.

Salami, M., Moosavi-Movahedi, A. A., Ehsani, M. R., Youseefi, R., Haertle, T., Chobert, J., ... Niasari-Naslaji, A. (2010). Improvement of the Antimicrobial and Antioxidant Activities of Camel and Bovine Whey Proteins by Limited Proteolysis. Journal of Agricultural and Food Chemistry., 58, 3297-3302.

Salami, M., Yousefi, R., Ehsani, M. R., Dalgalarrondo, M., Chobert, J. M., Haertlé, T. ... Moosavi-Movahedi, A. A. (2008). Kinetic characterization of hydrolysis of camel and bovine milk proteins by pancreatic enzymes. International Dairy Journal, 18(12), 1097-1102 https://doi.org/10.1016/j.idairyj.2008.06.003.

Satir, G., \& Guzel-Seydim, Z. B. (2015). Influence of kefir fermentation on the bioactive substances ofdifferent breed goat milks. LWT - Food Science and Technology, 63(2), 852-858 https://doi.org/10.1016/j.lwt.2015.04.057.

Sheng, Q., \& Fang, X. (2009). Bioactive components in Mare milk. In Y. W. Park (Ed.), Bioactive components in milk and dairy products, (2009th ed., ). WileyBlackwell https://doi.org/10.1002/9780813821504.ch7.

Shi, X., Chen, H., Li, Y., Huang, J., \& He, Y. (2018). Effects of kefir grains on fermentation and bioactivity of goat milk. Acta Universitatis Cibiniensis. Series E: Food Technology, 22(1), 43-50 https://doi.org/10.2478/aucft-2018-0005.

Shu, G., Shi, X., Chen, H., Ji, Z., \& Meng, J. (2017). Optimization of goat milk with ACE inhibitory peptides fermented by lactobacillus bulgaricus LB6 using response surface methodology. Molecules, 22(11) https://doi.org/10.3390/ molecules22112001.
Shu, G., Shi, X., Chen, L., Kou, J., Meng, J., \& Chen, H. (2018). Antioxidant peptides from goat milk fermented by lactobacillus casei 161: Preparation, optimization, and stability evaluation in simulated gastrointestinal fluid. Nutrients, 10(6) https://doi.org/10.3390/nu10060797.

Shuangquan, Tsuda, H., \& Miyamoto, T. (2008). Angiotensin I-converting enzyme inhibitory peptides in skim milk fermented with Lactobacillus helveticus 130B4 from camel milk in Inner Mongolia, China. Journal of the Science of Food and Agriculture, 88, 2688-2692.

Silva, S. V., Pihlanto, A., \& Malcata, F. X. (2006). Bioactive peptides in ovine and caprine cheeselike systems prepared with proteases from Cynara cardunculus. Journal of Dairy Science, 89(9), 3336-3344 https://doi.org/10. 3168/jds.S0022-0302(06)72370-0.

Soleymanzadeh, N., Mirdamadi, S., \& Kianirad, M. (2016). Antioxidant activity of camel and bovine milk fermented by lactic acid bacteria isolated from traditional fermented camel milk (Chal). Dairy Science and Technology, 96(4), 443-457 https://doi.org/10.1007/s13594-016-0278-1.

Soleymanzadeh, N., Mirdamadi, S., Mirzaei, M., \& Kianirad, M. (2019). Novel bcasein derived antioxidant and ACE-inhibitory active peptide from camel milk fermented by Leuconostoc lactis PTCC1899. International Dairy Journal., 97, 201-208 https://doi.org/10.1016/j.idairyj.2019.05.012.

Sultan, S., Huma, N., Butt, M. S., \& Shahid, M. (2017). Antihypertensive and Antioxidative potential of water soluble peptide fraction from different yoghurts. Journal of Food Processing and Preservation, 41(3), 1-7 https://doi. org/10.1111/jfpp.12979.

Tagliazucchi, D., Shamsia, S., \& Conte, A. (2016). Release of angiotensin converting enzyme-inhibitory peptides during in vitro gastro-intestinal digestion of camel milk. International Dairy Journal, 56, 119-128 https://doi.org/10.1016/j. idairyj.2016.01.009.

Tidona, F., Sekse, C., Criscione, A., Jacobsen, M., Bordonaro, S., Marletta, D., \& Vegarud, G. E. (2011). Antimicrobial effect of donkeys' milk digested in vitro with human gastrointestinal enzymes. International Dairy Journal, 21(3), 158165 https://doi.org/10.1016/j.idairyj.2010.10.008.

Tomazou, M., Oulas, A., Anagnostopoulos, A. K., Tsangaris, G. T., \& Spyrou, G. M. (2019). In silico identification of Antimicrobial peptides in the proteomes of Goat and Sheep Milk and Feta Cheese. Proteomes, 7, 32. https://doi.org/10. 3390/proteomes7040032.

Uniacke-Lowe, T., Huppertz, T., \& Fox, P. F. (2010). Equine milk proteins: Chemistry, structure and nutritional significance. International Dairy Journal, 20(9), 609629 https://doi.org/10.1016/j.idairyj.2010.02.007.

Wali, A., Yanhua, G., Ishimov, U., Yili, A., Aisa, H. A., \& Salikhov, S. (2020). Isolation and identification of three novel antioxidant peptides from the Bactrian camel milk Hydrolysates. International Journal of Peptide Research and Therapeutics, 26(2), 641-650 https://doi.org/10.1007/s10989-019-09871-X.

Wang, J., Li, C., Xue, J., Yang, J., Zhang, Q., Zhang, H., \& Chen, Y. (2015). Fermentation characteristics and angiotensin I-converting enzyme-inhibitory activity of lactobacillus helveticus isolate $\mathrm{H} 9$ in cow milk, soy milk, and mare milk. Journal of Dairy Science, 98(6), 3655-3664 https://doi.org/10.3168/jds. 2015-9336.

Wang, X., Zhou, J., Tong, P. S., \& Mao, X. Y. (2011). Zinc-binding capacity of yak casein hydrolysate and the zinc-releasing characteristics of casein hydrolysate-zinc complexes. Journal of Dairy Science, 94(6), 2731-2740 https:// doi.org/10.3168/jds.2010-3900.

Zanutto-Elgui, M. R., Vieira, J. C. S., do Prado, D. Z., Buzalaf, M. A. R., Padilha, P., Elgui de Oliveira, D., \& Fleuri, L. F. (2019). Production of milk peptides with antimicrobial and antioxidant properties through fungal proteases. Food Chemistry, 278, 823-831 https://doi.org/10.1016/j.foodchem.2018.11.119.

Zenezini Chiozzi, R., Capriotti, A. L., Cavaliere, C., La Barbera, G., Piovesana, S., Samperi, R., \& Laganà, A. (2016). Purification and identification of endogenous antioxidant and ACE-inhibitory peptides from donkey milk by multidimensional liquid chromatography and nanoHPLC-high resolution mass spectrometry. Analytical and Bioanalytical Chemistry, 408(20), 5657-5666 https://doi.org/10.1007/s00216-016-9672-z.

Zhang, Y., Chen, R., Ma, H., \& Chen, S. (2015). Isolation and identification of Dipeptidyl peptidase IV-inhibitory peptides from trypsin/chymotrypsintreated goat milk casein Hydrolysates by 2D-TLC and LC-MS/MS. Journal of Agricultural and Food Chemistry, 63(40), 8819-8828 https://doi.org/10.1021/ acs.jafc.5b03062.

\section{Publisher's Note}

Springer Nature remains neutral with regard to jurisdictional claims in published maps and institutional affiliations. 